\title{
Photomorphogenesis in Dracaena draco
}

\author{
Józef Krawczyszyn $^{1} \cdot$ Teresa Krawczyszyn $^{1}$
}

Received: 6 June 2015/Revised: 18 September 2015/Accepted: 25 September 2015/Published online: 27 October 2015

(C) The Author(s) 2015. This article is published with open access at Springerlink.com

\begin{abstract}
Key message Sunlight is a key environmental factor in growth, flowering and shaping of the Dracaena draco tree. Unidirectional light deforms the tree and may cause it to tilt.

Abstract Dracaena draco, a tree-like monocot, lives in cycles of vegetative growth and flowering. The cycles, as well as the tree growth form, are under genetic control. What controls their length has been unknown before. We propose that it is sunlight. Our trees of the same origin, growing for 20 years in the garden in varying sunlight conditions, started to flower when 9-12, 16 and 18-19 years old, for those growing in full sun, part shade and shade, respectively. In full sun, they grow shorter trunks than those in shade, catching overhead sun. Their branches also had shorter or longer growth and flowering cycles depending on sunlight availability. $D$. draco tree exhibited strong phototropic response and its crown was organized by the direction of growing tips. In full and in overhead sun, it had a regular form but asymmetrical in unidirectional, oblique sunlight. An asymmetrical crown and the absence of reaction wood may cause the $D$. draco tree tilting and progressive loss of balance.
\end{abstract}

Keywords Co-development - Dracaena draco - Dragon tree Ecological and genetic variations - Flowering cycle Reaction wood $\cdot$ Tilting

Communicated by J. Lin.

Józef Krawczyszyn

drjoe@dracaenadraco.com

1 Dracaena Draco Research Farm, Melbourne, VIC, Australia

\section{Introduction}

The dragon tree, Dracaena draco, is a relic of an ancient, Mio-Pliocene Southern Tethys flora (Marrero et al. 1998) endemic to a few Atlantic Ocean archipelagos and North Africa (Cabrera Pérez 1999). It is a monocot from Asparagaceae (subfamily Nolinoidae, Chase et al. 2009) with secondary growth and a tree-like habit (Hallé et al. 1978). As an iconic plant and a herbal symbol of the Canary Islands, it features in many botanic and Mediterranean gardens worldwide. The plant can attain a massive size and reach very old age (von Humboldt 1850, Gebauer 2009). "Drago Milenario" (or "El Drago") of Icod, Tenerife, is about $20 \mathrm{~m}$ high with a similar spread of the crown (Domínguez 2008). The plant, first mentioned in 1503 (Ommen 2009), is said to be about 400 years old (Mägdefrau 1975). How such a size is achieved is puzzling. The cellular structure and activity of its monocot cambium (secondary thickening meristem, STM), that is not homologous to the vascular cambium of dicot and coniferous forest trees (Zimmermann 1969; Carlquist 2012), is little known. The massive trunk seems to arise from the contribution of aerial roots that, growing from the low branches, join it increasing its waist (Krawczyszyn and Krawczyszyn 2014).

The trunk holds a crown made of many regular orders of branches, terminating with the tufts of leaves (Byström 1960; Symon 1974, 2000; Mägdefrau 1975) leading to a bizarre, umbrella-or mushroom-like shape of the tree. Branches, in view of fractal geometry (Mandelbrot 1982), are "self similar units" (Beyhl 1995, 2001). This shape comes from the growth pattern called dracoid habitus (Beyhl 1996) that requires each branch to grow only until it flowers and then to re-branch from its terminal buds. This is an adaptation of the tree to its Macaronesian habitat 
(Beyhl 1995). Stunning tree shape inspired many artists (Casper 2000; Guerra 2010) and computer programmers to show its unusual growth (http://www.Youtube: Fractaltrees).

Our working hypothesis is that variations in flowering lead the tree to morph into a variety of shapes so that any factor that affects flowering would also affect the shape of the tree. The following data suggested this idea:

1. The age at which flowering starts varies greatly: 9-10 years, (Symon 1974) 10-14 years (Byström 1960), 15-20 years (Mägdefrau 1975), 25 years (Baldwin personal comm., 2014), 27 years and nearing 30 years (Goodenough personal comm. 2015). At that time, the plant heights vary, too (Fig. 1). Sometimes, it never flowers.

2. The duration of the flowering cycle (i.e. the time period between two successive flowerings) varies from 10-11 years (Symon 1974) to 10-14 years (Byström 1960) and even 15-20 and more years (Mägdefrau 1975). Branches of the same order might flower at different times (Byström 1960; Symon 1974) or in synchrony, like the famous "El Drago of Icod" (Diaz, personal comm. 2010).

3. Our data (to be published) show that the plant could be self-pollinated, and the seedlings show hardly any variations in form until they are separated and grown in varying conditions.

We tested this hypothesis on our plants, grown from the seeds till flowering, in varying sunlight conditions in 20 -years trial. We also surveyed plants in the Canary Islands (Spain) during our trips in 2008-2010, trees in Adelaide (Australia) and also those we found online.

This paper reports our findings.

\section{Materials and methods}

We grown a group of $20 \mathrm{D}$. draco trees from seeds till flowering, some for 20 years. We grew them in our small farm in Hoppers Crossing (Australia). We also surveyed trees in Tenerife and La Palma, Canary Islands (Spain) during our three trips in July-September 2008-2010, and in Melbourne area (Australia), in Adelaide (Australia), and in Santa Barbara (California, USA).
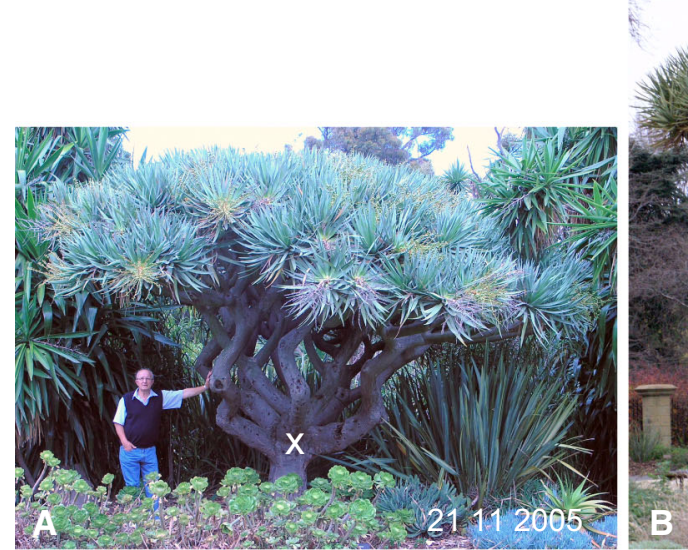

Fig. 1 Dracaena draco trees branching at various heights after they had set up their first flower spikes at various levels. a Melbourne Royal Botanic Gardens. b Geelong Botanic Gardens, Australia. c Punta Gorda, La Palma. d The Jardin Botánico, La Orotava,
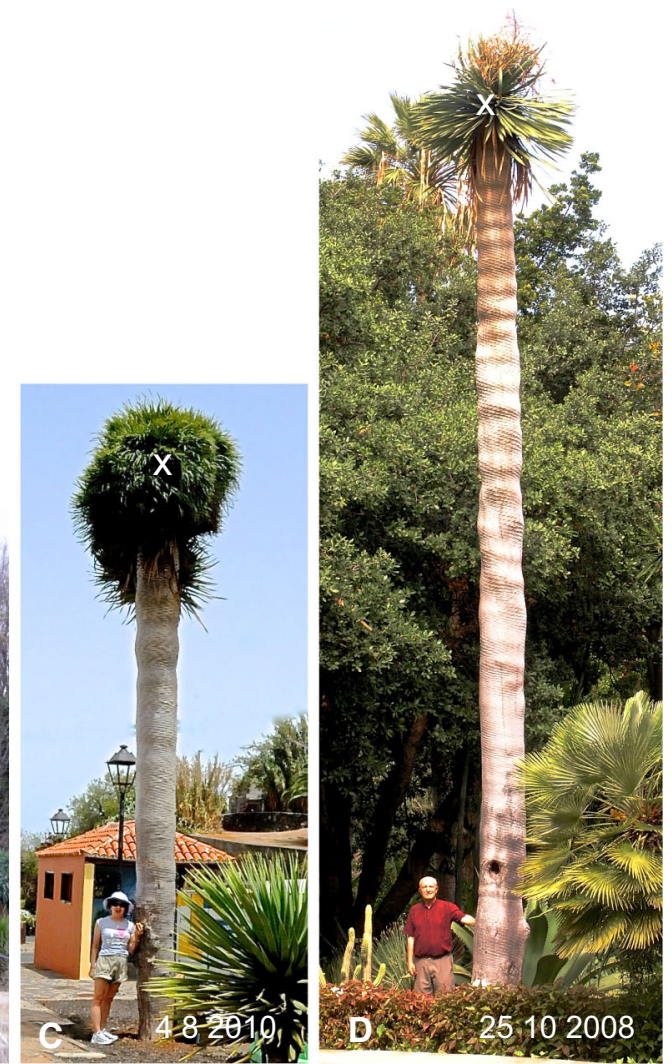

Tenerife, Spain. $X$ indicates the first branching point. Trees a, b, according to garden records, are of the Canary Islands origin as $\mathbf{c}$, d. Dates when the photographs were taken are also shown 
Hoppers Crossing, Vic, located on Western Basalt Plains poses a challenge to plant survival because of its poor, clay soil, its low rainfall (less than $600 \mathrm{~mm}$ ), as well as its hot, dry summers (average temperatures $25-27{ }^{\circ} \mathrm{C}$ ) and cold, frosty winters $\left(12-14{ }^{\circ} \mathrm{C}\right) \mathrm{http}: / / w w w . v e a c . v i c$. gov.au. Originally, we selected $D$. draco for its aesthetics and hardiness (Krawczyszyn, http://www.dracaenadraco. com/index_files) to make a house garden but we realized that it would be also suitable for a trial on growth and flowering.

Two groups of plants were used. One came from the seeds of the mother plant nicknamed "Essendon", from its second flowering. At that time, it grew in one of Melbourne's northwestern suburbs in full sun and developed a short, robust trunk and four thick branches forming a sharp angle with the trunk (Fig. 2a). Such shape is attributed to the Canary Islands form (Symon 1974). The plant and its progeny were designated as the " $R$ " plants. Another group came from the seeds of another mother plant. Its trunk was more slender than the "Essendon" plant. Later it started to grow a broad crown, with branches forming a wide angle with the trunk (Fig. 2b) as if it were of alternative, Cape Verdean form (Symon 1974) but whether or not it was of that form is not clear. It went to its first flowering in December 2001, and we used its seeds afterwards. This mother plant and its progeny were referred to as the " $S$ " plants. Steps involved in growing the " $R$ " and " $S$ " plants were similar (Table 1). Photographs were taken with Nikon D300.

Reaction anatomy was studied in one horizontal and one vertical branch, both 7 years old, in a tree shown in Fig. 2c. Tissue samples $(1 \times 2 \times 2 \mathrm{~cm}$ deep $)$ from both adaxial (upper) and abaxial (lower) side of each branch, from its base, middle and top (behind the oldest leaves) were taken. Thin cross sections were cut and analysed under the optical microscope. A single radial diameter of secondary tissues and 25 random secondary vascular bundles were measured with an ocular micrometre. Bundle density was determined for ten random areas, and the widths of cortex, monocot cambial zone and secondary tissues were measured three times.

\section{Results}

\section{Growth to maturity}

This was studied in plants " $\mathrm{S}$ " growing in full sun. 85 seedlings were planted in January 2004 (Fig. 3a). They were 1-year old already, each about 20 -cm tall with 10-12 leaves. At this stage, foliage makes the main body of the plant, the stem is short and covered by the bases of the leaves. All seedlings which originated from the seeds of the same mother plant show hardly any variation in appearance. Their growth was marked by their appearance, the elongation of new leaves at the top and dying of the old ones at the base.

Plants grew like that for the next 8 years. In 2012, 15 plants remained, with average height about $2.5 \mathrm{~m}$ and with about $1.5 \mathrm{~m}$ spacing (Fig. 3b). Four plants of this group flowered in November 2012 thus ending the first growth cycle. We measured one of them (an arrow in Fig. 3b) during 2003-2012 in November each year. Total height of the plant (from the base of the stem to the tips
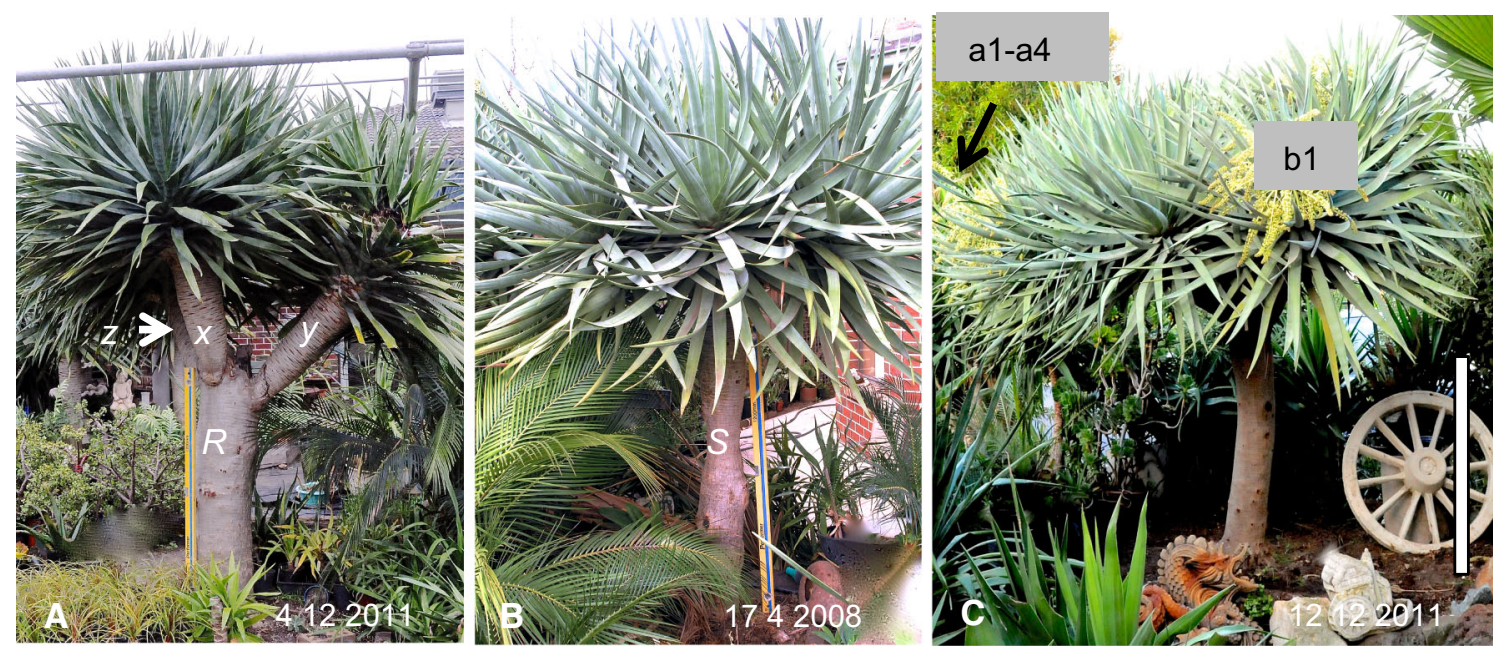

Fig. 2 a, b Mother plant "R" and "S", resp., whose progenies were grown from the seeds to flowering in varying sunlight. In a $x, y$ and $z$ are three out of four branches. c "Bunning" used in the study of flowering of branches in 1998-2013. Its main trunk flowered in 1998. $a 1-a 4, b 1$ The flowering of 2 nd order of branches. For details, see Table 3. Scale is $1.2 \mathrm{~m}$ 
Table 1 Steps in growing D. draco plants

\begin{tabular}{|c|c|c|c|}
\hline \multicolumn{2}{|c|}{ Tasks } & \multirow{2}{*}{$\begin{array}{l}\text { “R” plants } \\
\text { March } 1995\end{array}$} & \multirow{2}{*}{$\begin{array}{c}\text { "S" plants } \\
\text { Sept. } 2002\end{array}$} \\
\hline 1 & Seed collection & & \\
\hline 2 & Seed processing & Removal of fleshy, orange pericarp, cleaning, washing, drying & \\
\hline 3 & Seed germination & Oct. 1995 & Jan.-Feb. 2003 \\
\hline 4 & Medium & \multicolumn{2}{|l|}{ Seed raising mix Debco ${ }^{\circledR}$ on heated trays at $25^{\circ} \mathrm{C}$} \\
\hline 5 & Seedlings care & \multicolumn{2}{|c|}{$\begin{array}{l}\text { Seedlings appeared in } 4-5 \text { weeks. Moved to } 7.5 \mathrm{~cm} \text { tubes when having } 7-8 \text { leaves, about } 10-12 \mathrm{~cm} \text { tall. Grown until } \\
20-25 \mathrm{~cm} \text { tall }\end{array}$} \\
\hline 6 & Soil preparation & \multicolumn{2}{|c|}{$\begin{array}{l}\text { The soil (clay) was amended with gypsum, coarse sand and old mulch (each layer about } 3 \mathrm{~cm} \text { ). Cultivated to the } \\
\text { depth } 30 \mathrm{~cm}\end{array}$} \\
\hline 7 & Planting time & Spring (Oct.-Nov.) 1996 & Summer (Jan.) 2004 \\
\hline 8 & Place & Mostly back garden, close to the house, some in front of the house & Front of the house: two sides of the drive-way \\
\hline 9 & Planting method & Individually or in small (2-5) groups. Plants spacing $35 \mathrm{~cm}$ & 80 plants; spacing $35 \mathrm{~cm}$ \\
\hline 10 & $\begin{array}{l}\text { Sunlight } \\
\quad \text { availability }\end{array}$ & \multicolumn{2}{|c|}{$\begin{array}{l}\text { All plants were divided into groups A-N. Plants from groups A-G grew in full sun (in sunlight all day or most of the } \\
\text { day). } \mathrm{H}-\mathrm{J} \text { plants grew in partial shade of the garden, missing on some morning and afternoon sun. Plants of groups } \\
\mathrm{K} \text { and } \mathrm{L} \text { grew shaded by other trees receiving only some morning and some afternoon sunlight. Plants groups } \mathrm{M} \\
\text { and } \mathrm{N}-\text { shaded by the house, received only } 1-2 \mathrm{~h} \text { sun, mostly from overhead }\end{array}$} \\
\hline & Plant care & \multicolumn{2}{|c|}{$\begin{array}{l}\text { Watered 1-2 times/week in hot summers. Fertilized in spring with "Thrive"-soluble fertilizer. Thinned to avoid } \\
\text { overcrowding. At maturity, the distance b/n "S" plants was about } 2 \mathrm{~m} \text {. Plants nicknamed for identification }\end{array}$} \\
\hline
\end{tabular}

${ }^{a}$ See also Table 3
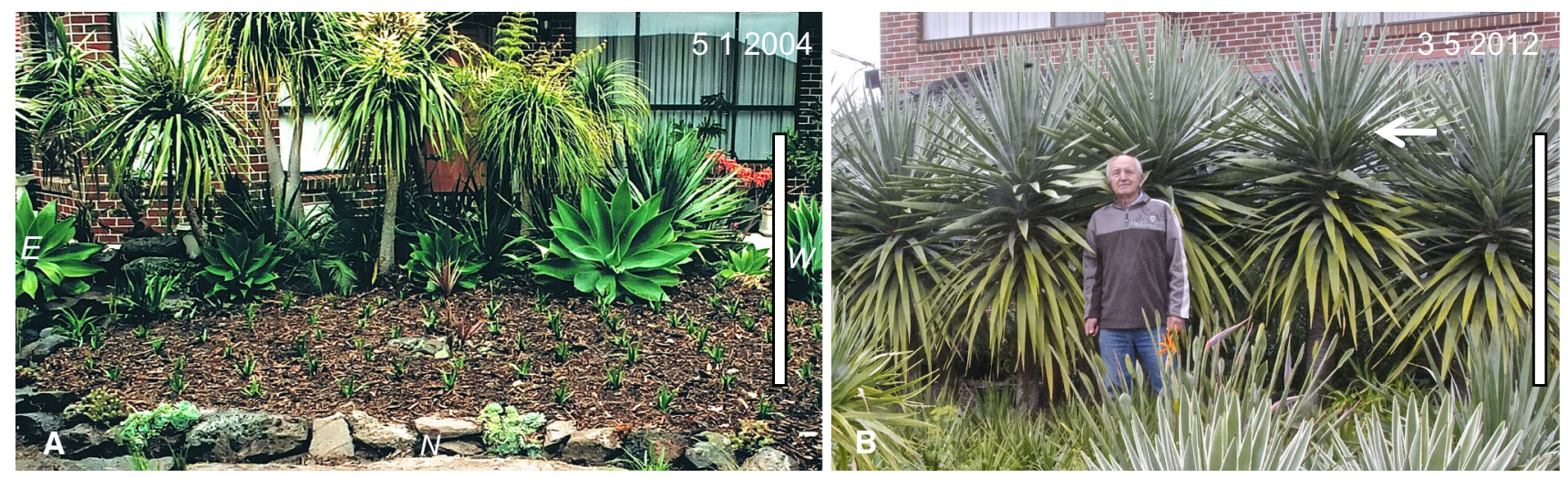

Fig. 3 Group of D. draco plants at the time of planting (a), and 8 years later (b). Plants grew in full sun. In a $E, W$ and $N$ are directions. Large plants from the back were later removed. Photograph b was taken 6 months before the first plants flowered in

of the leaves) and the height of the trunk itself were recorded, (Fig. 4). It reached total height of almost $2.5 \mathrm{~m}$ in 9 years. Its growth rate was $0.2-0.35 \mathrm{~m}$ per year with average value of $0.26 \mathrm{~m} / \mathrm{year}$. Between the third and the ninth year, stem height growth was parallel to total height growth. Later, with flowering, both kinds of growing stopped irreversibly.

\section{Onset of flowering in sun and shade}

Data on flowering of all 20 plants, some growing for 20 years, in varying sunlight conditions are presented in
November 2012. In b arrow indicates the plant that has been measured during 2004-2012. Dates when the photographs were taken are shown. Scale is $1.75 \mathrm{~m}$

Table 2. Plants originated from the seeds of two mother plants: an R and an S, (Fig. 2a, b, resp.). All 20 plants in Table 2 are grouped into four clusters (column 1, groups A-N and column 6) starting from those that received most sunlight (groups $A-G$ ), to those that received the least and mostly overhead sunlight (group $\mathrm{M}, \mathrm{N}$ ).

In this trial, all 20 plants flowered at ages ranging from 9 to 19 years. Almost half of them (13) flowered when 9-12 years old, regardless of origin ( $\mathrm{R}$ or $\mathrm{S}$ ). They grew in full sun all day or most of the day. Five plants flowered at the age of 9 years and three at the age of 10 years (group A and $\mathrm{C}$, Table 2). They were a part of a larger group, already 


\begin{tabular}{|c|c|c|c|c|c|c|c|c|c|c|c|}
\hline $\mathbf{A}$ & Calendar year & 2003 & 2004 & 2005 & 2006 & 2007 & 2008 & 2009 & 2010 & 2011 & 2012 \\
\hline & Growth year & 1 & 2 & 3 & 4 & 5 & 6 & 7 & 8 & 9 & 10 \\
\hline & ant height, total ${ }^{*}$ & 0.2 & 0.46 & 0.8 & 1.1 & 1.38 & 1.62 & 1.85 & 2.18 & 2.4 & 2.4 \\
\hline & Stem height * & 0.01 & 0.04 & 0.2 & 0.47 & 0.75 & 1.0 & 1.28 & 1.65 & 1.9 & 1.9 \\
\hline & Growth rate ** & 0.2 & 0.26 & 0.34 & 0.21 & 0.30 & 0.24 & 0.23 & 0.3 & 0.25 & 0 \\
\hline
\end{tabular}
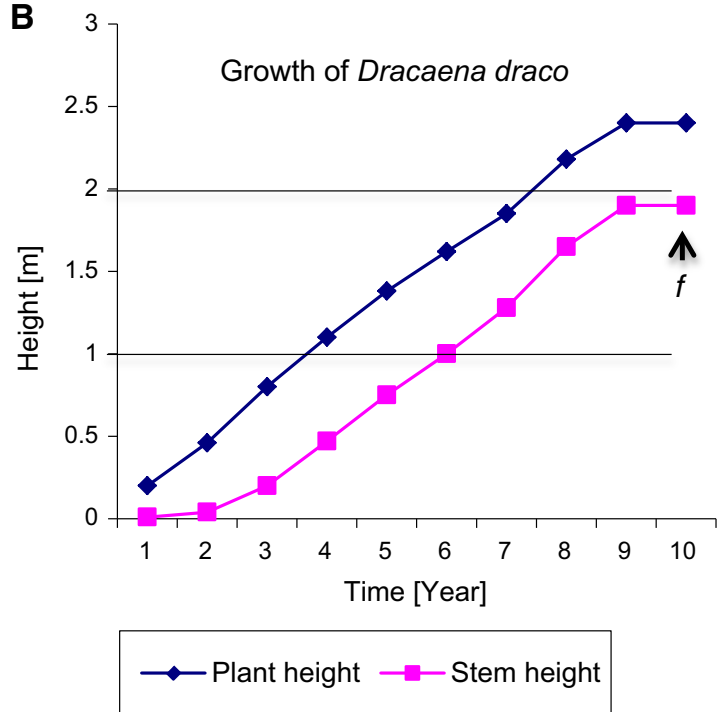

* in $\mathrm{m:}{ }^{* *}$ in $\mathrm{m} /$ year

Fig. 4 a Numerical data on growth of the D. draco tree shown in $3 \mathrm{~b}$ (arrow) from the seedling to first flowering. b Relation between growth and time and $\mathbf{c}$ the rate of growth in the first growth cycle. The

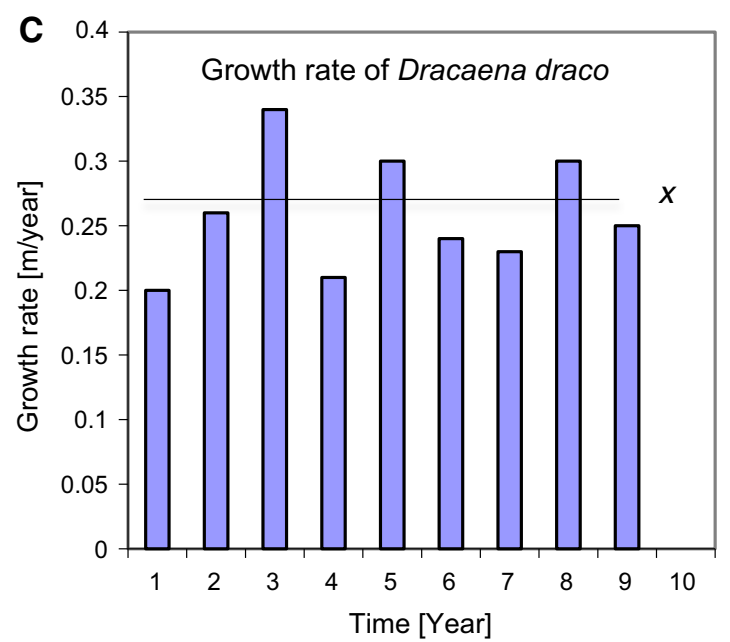

plant grew in full sun. In $\mathbf{b}, f$ marks flowering. In $\mathbf{c}$, horizontal line $x$ shows an average growth rate, $0.26 \mathrm{~m} /$ year. Plant height total height of the plant from the bottom of the stem to tips of the leaves
Table 2 Flowering age of $D$. draco in varying sunlight conditions

\begin{tabular}{|c|c|c|c|c|c|c|c|}
\hline 1 & 2 & 3 & 4 & 5 & 6 & 7 & 8 \\
\hline \multicolumn{4}{|c|}{$\mathrm{PI}$ a $\mathrm{nts}$} & Trunk & Sunlight & Growing & Flowering \\
\hline Group & Name & Origin & Numbers & height [m] & availability & cycle & age / years \\
\hline A & Fronta L4 & $S$ & 4 & $2.4 \pm .05$ & \multirow{7}{*}{$\begin{array}{l}\text { All day } \\
\text { or most } \\
\text { of the day }\end{array}$} & $2003-2012$ & 9 \\
\hline$B$ & Fronta R1 & $S$ & 1 & 1.7 & & $2003-2012$ & 9 \\
\hline C & Fronta Lab & $S$ & 2 & $2.45 \pm .05$ & & $2003-2013$ & 10 \\
\hline $\mathrm{D}$ & Virginia & $\mathrm{R}$ & 1 & 1.1 & & $2003-2013$ & 10 \\
\hline$E$ & Ircia & $\mathrm{R}$ & 2 & $1.6 \pm .05$ & & $1995-2006$ & 11 \\
\hline $\mathrm{F}$ & Elissa & $\mathrm{R}$ & 1 & 1.14 & & $1995-2007$ & 12 \\
\hline G & Vasa & $\mathrm{R}$ & 2 & 1.2 & & $1995-2007$ & 12 \\
\hline
\end{tabular}

\begin{tabular}{|c|l|l|l|l|l|l|c|}
\hline $\mathrm{H}$ & Shirley & $\mathrm{R}$ & 1 & 1.7 & Some, & $1995-2011$ & 16 \\
\hline $\mathrm{I}$ & Terenia & $\mathrm{R}$ & 1 & 1.75 & \multirow{2}{*}{$\mathbf{n}$} & $1995-2011$ & 16 \\
\hline $\mathrm{J}$ & Monsta & $\mathrm{R}$ & 1 & 2.65 & & $1995-2011$ & 16 \\
\hline
\end{tabular}

\begin{tabular}{|l|l|l|l|l|l|l|c|}
\hline $\mathrm{K}$ & Bdroomia & $\mathrm{R}$ & 1 & 1.75 & Little, & $1995-2013$ & 18 \\
\hline $\mathrm{L}$ & Ponda & $\mathrm{R}$ & 1 & 2.1 & & $1995-2013$ & 18 \\
\hline $\mathrm{M}$ & Julie & $\mathrm{R}$ & 1 & 2.75 & Very little & $1995-2014$ & 19 \\
\cline { 1 - 4 } \cline { 6 - 8 } & & $1995-2014$ & 19 \\
\hline
\end{tabular}

Plants are divided into groups A-N and nicknamed (columns 1 and 2). The plant numbers in each group (column 4) varied depending on space available. For details of plants light conditions see Materials and Methods. Trunk height (column 5) - height of the trunk up to the branching point. End of growing cycle (in column 7) was marked by appearance of inflorescence in Nov.-Dec. of a particular calendar year 
presented in Fig. 3b and grew in the front row, on the North-West side thus receiving the most sunlight available. Two other plants from this group (presented in Fig. 3b) flowered when 10 years old (in Table 2 they are referred to as "Fronta Lab"). They were also from the front row (as those from group A) but they received less morning and afternoon sun than their neighbours. A single plant (group $\mathrm{B}$, from the other side in front of the house) that was also in full sun flowered when 9 years old. The remaining plants growing in full sun (groups D-G) flowered when $10-12$ years old.

Regarding seven other plants: three of them flowered at the age 16, two at the age 18 years and two when 19 years old. Those that flowered last grew close to the house receiving sunlight mostly from overhead i.e. less than those flowering 2 years earlier (plants $\mathrm{H}-\mathrm{J}$ ). Mean values of flowering age were $10.2 \pm 1.2$ years (group A-G) and $17.4 \pm 1.2$ years (group $\mathrm{H}-\mathrm{N}$ ). These two ages differ from each other significantly ( $p>0.01, t$ test). These data show a close relationship between the amount of sunlight the plant receives and the age of its first flowering. The availability of sunlight is then a factor in flowering of the D. draco tree.
Table 2 also shows that the trees growing in varying light conditions greatly differ in trunk height. Generally, trees from full sun (plants groups A-C) start branching closer to the ground and grow shorter than those that grow with less sunlight catching it from overhead (groups F-H). This is demonstrated in Fig. 5 that presents plants of the same origin $(\mathrm{R})$ growing in varying light conditions. Plants from the sun (Fig. 5a, b) are about a half as high as plants from the shade (Fig. 5d, e).

This relationship is further illustrated in Fig. 6 showing the same plants as in Fig. 5 arranged on the same time scale according to the time of onset of flowering. There are individual differences between plants listed, yet there is a general trend to delay of the onset of flowering with an increase of the height of the tree as less and less sunlight is available.

Figure 6 also shows that plants living in shade grow taller trunks (before they flower and branch) than those in the sun. But they do not appear to grow faster. As an example, the growth rate of the trunk, in m/year, calculated for the shortest and for the tallest plants (Fig. 5a versus d) is similar, at 0.11 and $0.16 \mathrm{~m} /$ year, respectively. Average growth rates, in m/year, calculated for plants

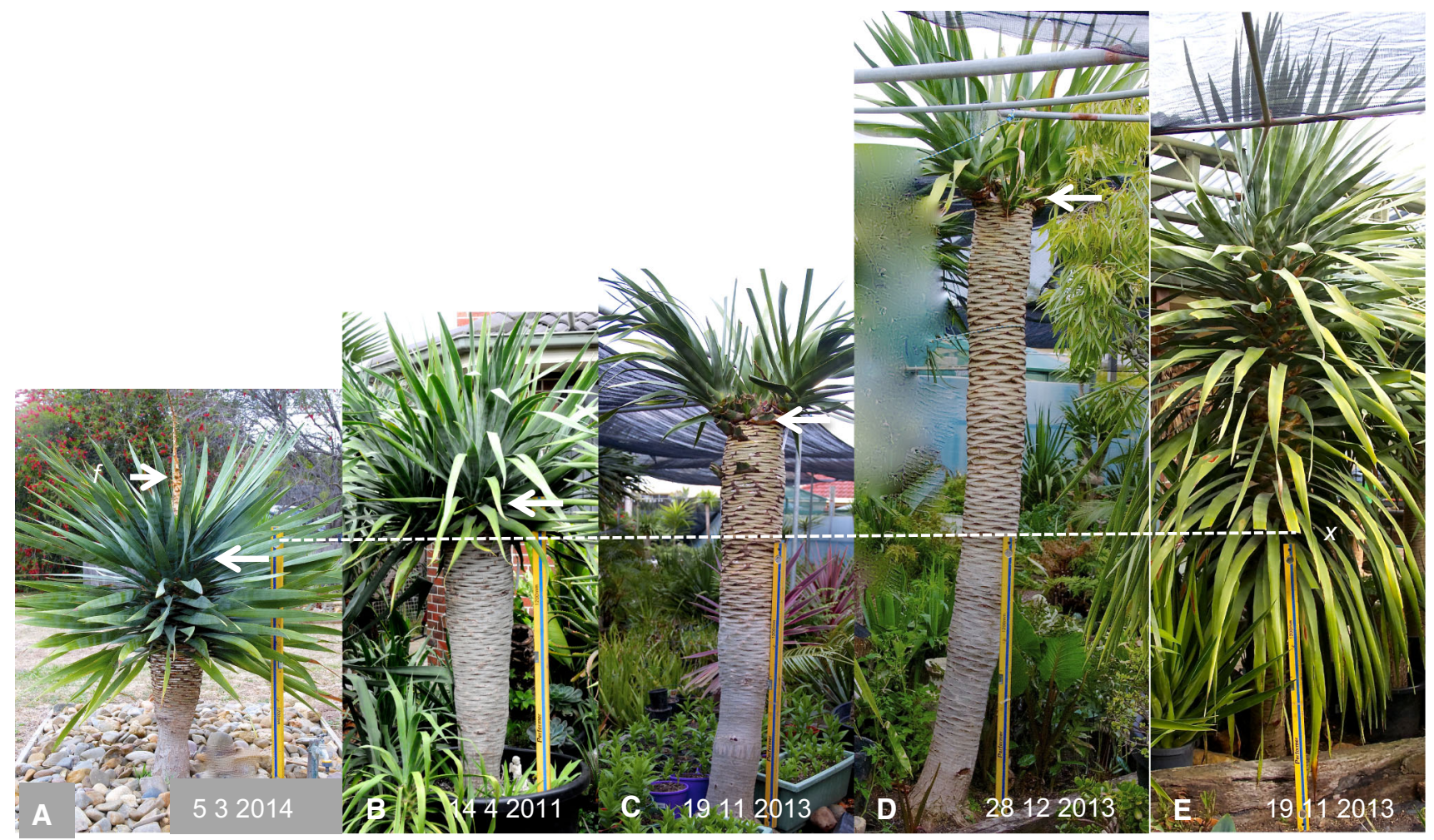

Fig. 5 D. draco plants of the same origin, which have been growing in varying sunlight conditions, at beginning of branching (see Table 2). a "Virginia" ( $f$ indicates the stalk of the former inflorescence). b "Elissa" branching after flowering at the age 12. c, d "Terenia" and "Monsta" (respect.) that flowered when 16 years old, after their top leaves reached the sunlight from above garden shedding and the gutter of the house. e Julie, 18-year old yet still not flowering by February 2014. Time-taking photographs are also shown. Scale is $1.2 \mathrm{~m}$. $x$ line is drawn $1.2 \mathrm{~m}$ high, to show the relative height of the trunks when branching begins, arrows. In b-d, to visualize trunks and branching, the leaves were cut off about $3 \mathrm{~cm}$ above their bases and let to dry and to fall 


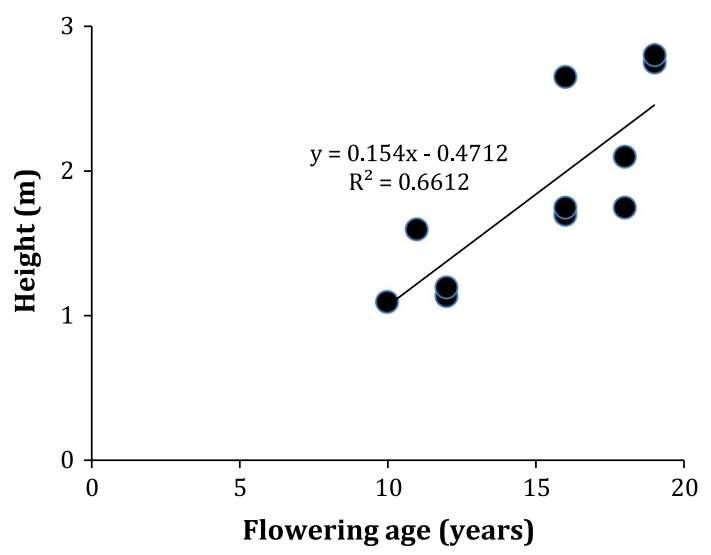

Fig. 6 Relationship between the height at which plants start to branch and their flowering age for the R-plants listed in Fig. 5

from groups A-G, H-J and $\mathrm{K}-\mathrm{L}$ (Table 2) are 11.5; 12.6 and 11.6, respectively. This means that all plants grow at a similar rate but short plants grow for much shorter time periods, so they flower sooner and start branching closer to the ground.

Plants presented in Fig. 5, despite growing in different sunlight conditions and flowering at varying times, developed similarly robust trunks like their mother plant. On the other hand, their mature leaves vary in size and firmness: they are short and strike out on plants exposed to full sun (Fig. 5a) but are long and droopy on plants in the shade (Fig. 5e). This means that the trunk forms were controlled genetically, while leaf size and appearance were more likely to be influenced by the environment.

\section{Sunlight availability and flowering of branches}

Flowering of the branches was recorded in three young trees. The first one, "Essendon" (Fig. 2a), was planted in 1997 as a stump; its previous owner cut off its four branches, each about 1-1.5-m long. The stump re-grew four new branches. Two of them flowered in 2006 when 9 years old. They received most of the sun from Northwest (Fig. 2a; x, y). Another one (not seen in Fig. 2a) flowered in 2009, when 12 years old. The last one, Fig. 2a; z, receiving the least sun flowered in 2011 at the age of 14 .

Plant "Ircia" (Table 2, E) came from the seeds of "Essendon" (Fig. 2a) that germinated in 1995. It flowered first in 2006, when 11 years old. Later it grew seven branches with two flowering in 2013 i.e. when 7 years old. They were exposed to the most sun (North-West).

The third plant "Bunning" was acquired from the nursery when about 1-m tall. In our place, it flowered first in 1998. Over the next 15 years, it developed quite sizeable crown, Fig. 2c. Its full record of flowering and branching during that time is presented in Table 3. After the first flowering (1998), it produced four branches of the 1st
Table 3 Flowering of branches in "Bunning", Fig. 2c

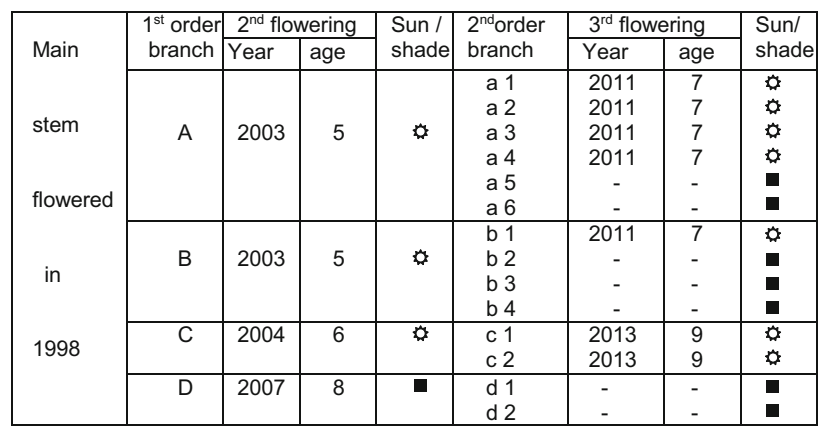

order. They flowered when 5, 6 and 8 years old. Later, they grew together 14 branches of the 2 nd order. Half of them (seven) flowered after 7-9 years, while another half did not flower by that time. On average, the branches of the 1st order flowered after 6 years of growth, while those of the 2nd order 1.5 years later. It also appeared that branches from the sunny side of the tree grow shorter than those from the shade, which may lead to an asymmetric crown.

These data show that branches of a particular tree may take a variable time to flower (thus to complete their growth and to fork) depending on the amount of sun they receive. Branches exposed to the sun flower sooner than those in the shade. Branches that flower later (in shade) grow longer than those from exposed to the sun and may attain larger axial dimensions. This, over a long period of time, would lead to an asymmetric crown bending towards the sun.

\section{Unidirectional sunlight, tree asymmetry and tilting}

Dracaena draco trees that grow in one-sided light turn to that light and may tilt, Fig. 7. Our tree in Fig. 7a, from the edge of our full sun group, is leaning towards the North (prevailing direction of sun) by about $15^{\circ}$ off the vertical, while its neighbours from the middle of the group are vertical. Three other trees from the group shown in Fig. 3b, from the front row (referred to as "Fronta L4" and two as "Fronta Lab", see Table 2), also tilted, especially with the appearance of fruit so we had to straighten them with rope. Another tree, "Essendon" planted as a branch-less stump also started to lean North after the reappearance of new branches, as shown in Fig. $7 \mathrm{~b}$.

We found some similar, tilting trees in La Laguna (Tenerife), the oldest city in the Canaries (Fig. 7c-e). The massive trunk presented in Fig. $7 \mathrm{c}$ is straight on the front view but leaning $12^{\circ}$ from the vertical when seen from the side, Fig. 7d. (NB a half of its crown, $x$ in Fig. 7c, was deliberately removed so it is missing). 

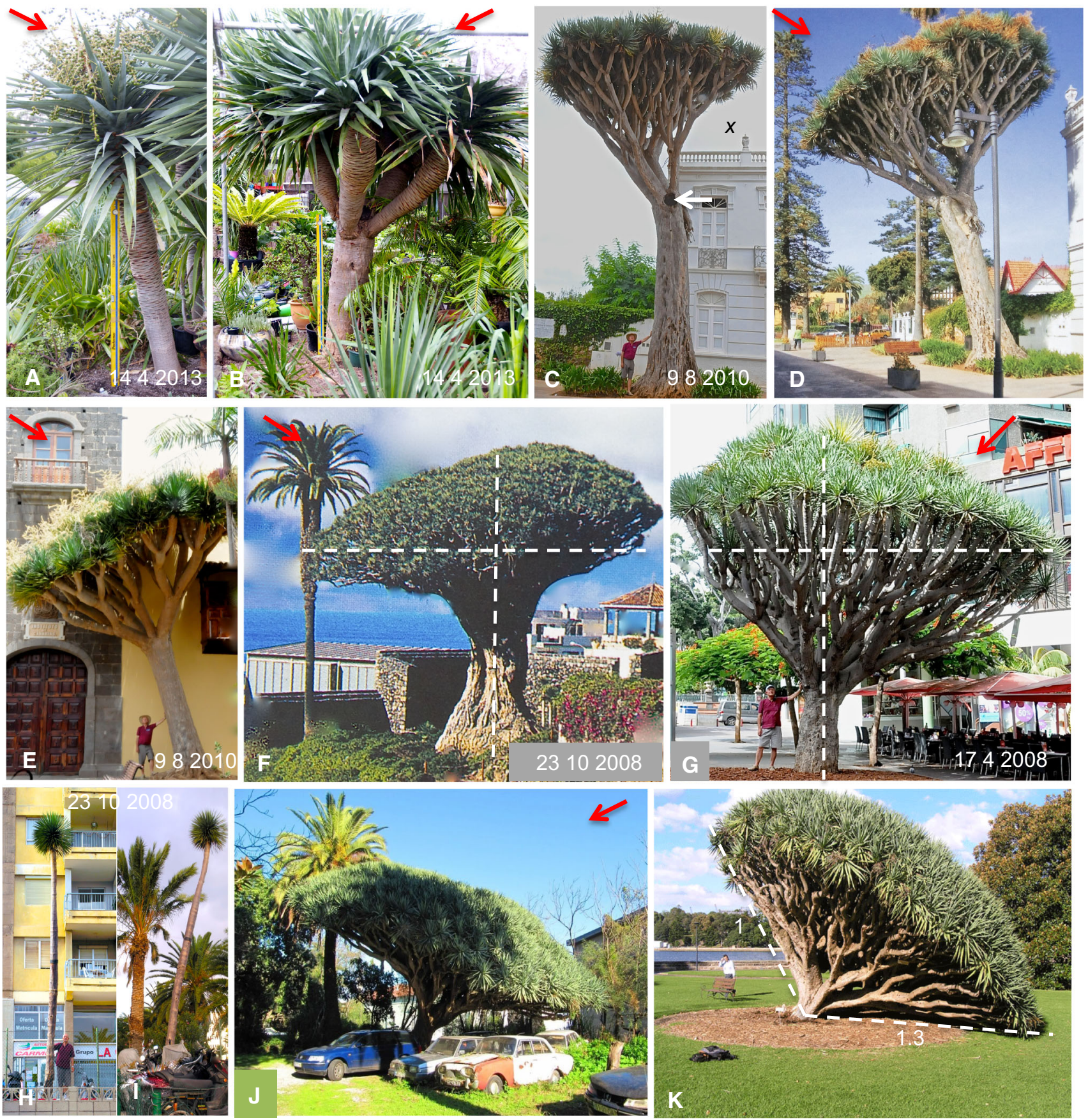

Fig. 7 Deformities of the $D$. draco trees in unidirectional sunlight. a 10 years old and b about 35 years old tree, both in Hoppers Crossing, Melbourne. c, d La Laguna, Plaza de la Junta Suprema, Tenerife, Spain. The same tree in front and side view. e La Laguna, Instituto de Canarias. f El Drago of Icod, Tenerife. g St. Cruz de Tenerife, Plaza del Principe. h, i "Drago Macho" in St. Cruz de Tenerife, Calle Jose Hernades x Tres de Mayo. About 8-m tall tree leaning to the street in 2008 and removed by August 2009. j Tree

Another tree, Fig. 7 e, tilting about $10^{\circ}$ off the vertical, looks like it is falling down already. Its crown shaped like an asymmetric inverted pyramid has its longer branches on its shady side than on the other side as if they grew faster. in Palácio Pancas, Lisbon, Portugal by Bico, online. k Overturned tree in Sydney Botanic Garden with asymmetrical crown (online). In $\mathbf{a}, \mathbf{b}$ the $1.2 \mathrm{~m}$ scale is oriented vertically. In $\mathbf{c}, x$ indicates the missing part of the crown, deliberately cut due to hazardous leaning; an arrow shows the scars. Red arrows indicate the anticipated prevalent sun. In $\mathbf{f}$ and $\mathbf{g}$, dashed lines show axes of symmetry and in $\mathbf{k}$ relative (1:1.3) length of the branches. Photographs $\mathbf{j}$, k retrieved 15 February 2014. d Courtesy Ediciones, Tenerife, Spain

On both sides of the crown, we found mostly four forking points meaning that the tree was still flowering synchronously. We witnessed the last flowering in August 2009. 
The El Drago of Icod (Tenerife island) is known for its regular, umbrella-like shape. But it looks like that when viewed from a tourist spot; from another spot, its crown is lower on one side and taller on the other one, and its trunk is twisted, Fig. 7f. An asymmetric crown is also seen in the tree from St Cruz de Tenerife, presented in Fig. $7 \mathrm{~g}$ with the most of its vertical branches growing towards sunlight it receives mostly from overhead.

A trunk growing off the vertical is also seen in the very tall, single stemmed plant from St Cruz de Tenerife, in Fig. 7h, i. Such a plant, as the locals believe, would never flower nor branch so they refer to as "Drago Macho""male dracaena". The tree in Fig. 7i grows off the vertical towards a free space, with sun and later it started to straighten and grew vertically.

In our quest for other tilting dragon trees, we also visited a collection of photographs by Bico (online). They represent mostly the Cape Verdean growth form with trunks that usually branch low. Out of about 65-70 trees viewed, 7-8 show trunks leaning off the vertical towards the sun, Fig. 7j. Finally, we found a tree of a similar, Cape Verdean form in Royal Sydney Botanic Garden, Fig. 7k, asymmetrical and overturned, http://www.abc.net.au/local/stor ies/2008/05/07/2238240.htm.

Anatomical responses of the $D$. draco to tilting are not known. Some insight may come from the scars left after the limbs are removed. Figure $8 \mathrm{a}, \mathrm{b}$ presents two old scars. The first one is on the tree shown in Fig. 7c, d. Located about
$5 \mathrm{~m}$ high, it is about $0.5-\mathrm{m}$ long and a few years old as seen from the callus bulging off the bark side. The second scar is covered by the thick layer of callus, yet it shows an area of primary tissues $(\mathrm{x})$ and secondary tissues (lines). Both scars are eccentric with much thicker secondary tissues deposited on the lower (abaxial, ab) sides. It means that the monocot cambium of the branches was more active on the lower side.

Figure $8 \mathrm{c}$ presents another large scar. The absence of callus formation and fresh protective paint suggests that the branch was cut off shortly before we saw it in 2008 . It reveals an area of former primary growth enclosed by circles of "growth rings". The first such "rings" are circular but recent ones are eccentric so that the abaxial side of secondary tissues (ab) is about nine times wider than the adaxial (ad) side. It means that a young branch deposited secondary tissues evenly as if it were oriented vertically. Later, it added more and more these tissues to its lower side, as if it were growing horizontally, before it was removed. Extremely eccentric scars shows an old, historic Vandelli tree in Ajuga Botanic Garden (Lisbon, Portugal) left after removal of its horizontal branches, Fig. 8d. The primary tissues are rot out. They are much shifted towards the adaxial side meaning that its monocot cambium deposited much more secondary tissues on their lower side, which was more exposed to compression from gravitational forces. In result, the branches on

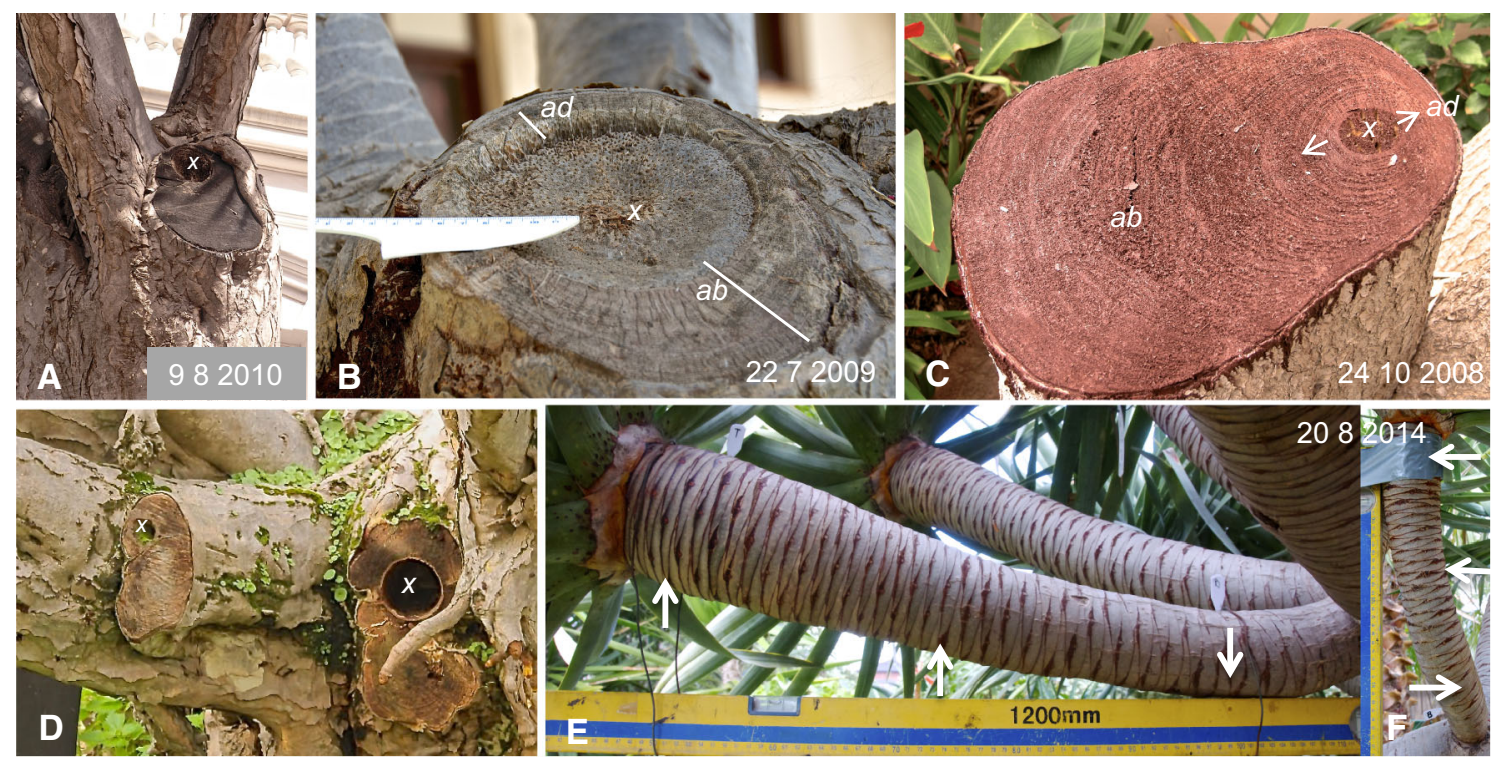

Fig. 8 Adaptive growth in D. draco. Scars showing asymmetric growth of the branches: $\mathbf{a}$ on the tree presented in Fig. 7c, d, b, c on two other trees, d on historic Vandelli tree, Ajuda Botanic Garden, Lisbon, Portugal. e, f Horizontal and vertical branches (respect.) in the tree analysed in Table 4 . In a-d, $x$ indicates the former primary growth. In b, c, $a b$ and $a d$ indicate abaxial and adaxial sides, respectively. In $\mathbf{b}$, lines indicate secondary tissues on both sides of the branch. In c, arrows show an area with symmetric "growth rings". In e, f, arrows indicate samplings areas. a-c La Laguna, Tenerife, Spain. d Lisbon, Portugal, courtesy Bico. e, f Hoppers Crossing, Australia. Scale in $\mathbf{b}, \mathbf{e}, \mathbf{f}$ in $\mathrm{cm}$ 
the cross sections are oval with long, vertical sides, Fig. 8d.

We surveyed the reaction anatomy of the tree "Bunning", Fig. 2c, after sampling its two branches: one horizontal and one vertical, both 7 years old Fig. 8e, f. Top, middle and base of the branches were sampled and analysed under the optical microscope, Table 4.

In both, vertical and horizontal branches, at the base and in the middle, the monocot cambium is present (column 5). Its derivatives - the secondary vascular bundles-are present too. In the top of the vertical branch, this meristem is present too but only on its abaxial side and without any secondary vascular bundles yet (column 5). All this means the forthcoming change from the primary to the secondary body in the branches. In the vertical branch, the secondary tissues in both adaxial and abaxial sides (column 4) have similar radial dimensions and the vascular bundles also have similar radial and tangential dimensions (column 6). In the horizontal branch, the secondary tissues occur on both adaxial and abaxial sides but they are much thicker on the lower side than in the upper side (6.6 versus $4.2 \mathrm{~mm}$, column 4). The vascular bundlers on the lower side of this branch also have larger radial dimensions $(0.5$ versus $0.4 \mathrm{~mm}$, column 6), so that their density $/ 1 \mathrm{~mm}^{2}$ is lower there.

\section{Discussion}

Plants are modular organisms. They grow by making similar modules and they change when affected by environment, mostly light. $D$. draco is composed by similar units, too, and is a very variable plant. This part will discuss some of its architectural features and how sunlight causes it to morph into a variety of growth forms.

\section{Modularity and the tree architecture of the dragon tree}

Plants grow by adding of similar units that for every species remain stable through life. Modularity allows best use of light and space and provides for flexibility needed in ever changing environment. This idea is also a key to our view of plants growth (Dyrynda 1986; Jorgensen and Olesen 2000; Del Tredici 2002; Ferraro et al. 2005; Wyk and Wyk 2007; Mori and Niimets 2010; http://www.eerc. unsw.edu.au/research-P3).

A module of a Dicot tree is usually a short internode with a node, leaf and bud (Wyk and Wyk 2007). A module of $D$. draco (i.e. unit, trunk, branch) could be up to a few metres long and, as revealed by leaf scars, has several spirals of leaves confined to the Fibonacci series. As an example, the trunk of "Elissa" has 8 clockwise (Z) spirals

Table 4 Measurements of tissues in a horizontal and vertical branch of D. draco

\begin{tabular}{|c|c|c|c|c|c|c|c|}
\hline \multirow{4}{*}{$\begin{array}{l}1 \\
\text { Place and radius, mm }\end{array}$} & \multirow{4}{*}{$\begin{array}{l}2 \\
\text { Side }\end{array}$} & \multirow{4}{*}{$\begin{array}{l}3 \\
\text { Cortex and } \\
\text { Periderm, mm }\end{array}$} & \multirow{4}{*}{$\begin{array}{l}4 \\
\text { Secondary } \\
\text { tissues, mm }\end{array}$} & \multirow{4}{*}{$\begin{array}{l}5 \\
\text { Monocot } \\
\text { cambium, mm }\end{array}$} & \multicolumn{3}{|l|}{6} \\
\hline & & & & & \multicolumn{3}{|c|}{ Vascular bundle } \\
\hline & & & & & \multicolumn{2}{|c|}{ Diameter, mm } & \multirow[t]{2}{*}{ Density, no./mm 2} \\
\hline & & & & & Radial & Tangential & \\
\hline \multicolumn{8}{|l|}{ Vertical branch } \\
\hline \multirow[t]{2}{*}{ Top (r-41) } & Adaxial & 2.28 & Absent & Absent & Absent & & \\
\hline & Abaxial & 2.28 & Absent & $0.19-0.24$ & Absent & & \\
\hline \multirow[t]{2}{*}{ Middle (r-36) } & Adaxial & 2.4 & 1.9 & $0.15-0.23$ & 0.37 & 0.22 & 4.0 \\
\hline & Abaxial & 2.66 & 1.8 & $0.14-0.23$ & 0.39 & 0.23 & 4.3 \\
\hline \multirow[t]{2}{*}{ Base (r-33) } & Adaxial & 2.8 & 2.7 & $0.24-0.27$ & 0.38 & 0.23 & 4.5 \\
\hline & Abaxial & 2.7 & 2.3 & $0.23-0.28$ & 0.39 & 0.22 & 4.7 \\
\hline \multicolumn{8}{|l|}{ Horizontal branch } \\
\hline \multirow[t]{2}{*}{ Top (r-58) } & Adaxial & 2.5 & Absent & Absent & Absent & & \\
\hline & Abaxial & 2.5 & Absent & Absent & Absent & & \\
\hline \multirow[t]{2}{*}{ Middle (r-44) } & Adaxial & 2.5 & 2.7 & $0.19-0.24$ & 0.51 & 0.24 & 3.4 \\
\hline & Abaxial & 2.6 & 2.8 & $0.20-0.25$ & 0.57 & 0.28 & 3.5 \\
\hline \multirow[t]{2}{*}{ Base (r-39) } & Adaxial & 2.0 & 4.2 & $0.34-0.39$ & 0.4 & 0.27 & 5.1 \\
\hline & Abaxial & 2.6 & $6.6^{*}$ & $0.33-0.38$ & $0.50 *$ & 0.31 & $3.1 *$ \\
\hline
\end{tabular}

Samples were taken 22-25 August 2014. For sampling, see Materials and methods

* Significant difference between adaxial (upper) and abaxial (lower) sample 

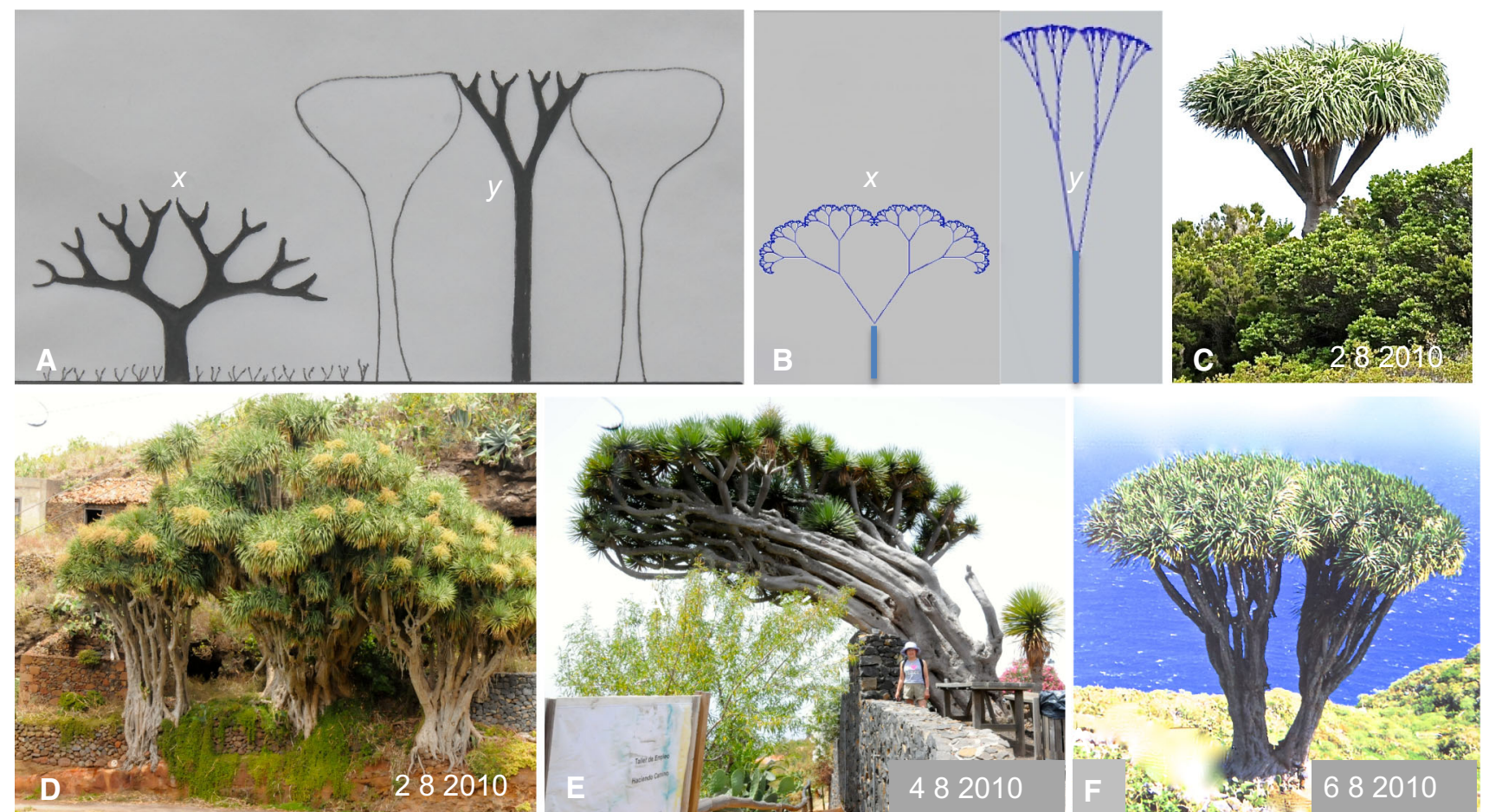

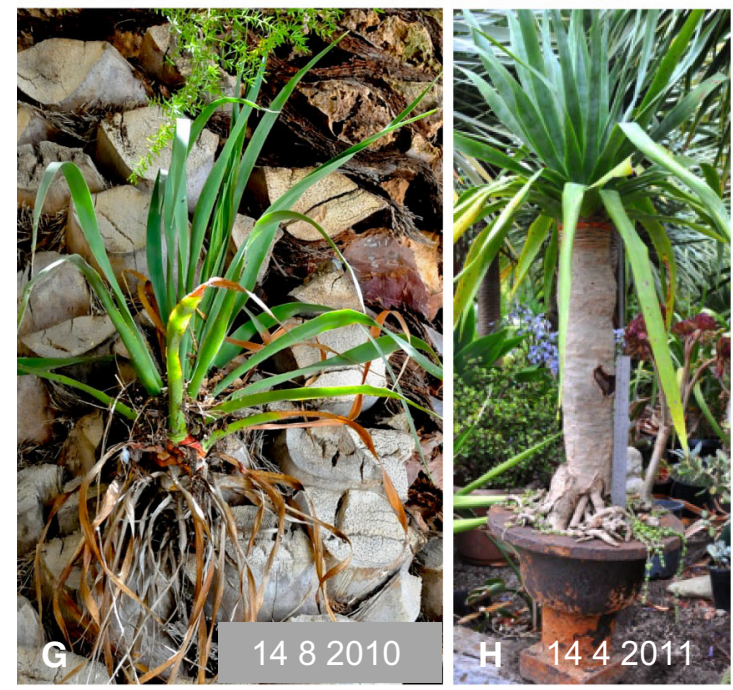

Fig. 9 Environmental effects on growth form of D. draco. a The "sun" and "shade" trees ( $x$ and $y$, respect.). For details, see text. b Computer models of fractal trees that correspond to "sun" and "shade" trees (source: online). c A tree with flat canopy in La Tosca, Nth La Palma, in a visual distance from a group of multiheaded trees, d. e "Drago de Punta Gorda", Nth La Palma, growing in a wind. f A pair of trees in Garafia, Nth La Palma. g Young D. draco plant on the surface of Phoenix canariensis palm in La Laguna, Tenerife. h 16- year-old plant, growing in a cast iron vase. i Miniature, pot plants in our place in Hoppers Crossing. Plants $x, y, z$ are about 10 years old each. j D. draco tree in a hanging basket in Pension Mova St. Cruz De Tenerife. $v$ indicates a new growth from the base of the trunk (courtesy Javier). In 2010, it was 12 years old. Its leafless stem was $1.2-\mathrm{m}$ long and $1.5 \mathrm{~cm}$ in diameter. Dots indicate bending of the stem. Scale in $\mathbf{h}, \mathbf{i}$ is $30 \mathrm{~cm}$ (or 13 anticlockwise, S, spirals), in another two plants, we noted $8 \mathrm{Z} / 5 \mathrm{~S}$ spirals, and in a third one, 13Z/8S spirals. Stem of "Elissa" grew, during the 1st cycle, about 500 leaves, while the other trees grew about 700 each. Each leaf has an axillary bud. A mature unit holds about 50,000 flowers (Symon 2004). Erect, sympodial trunk of D. draco holds many sets of branches that grew from the lateral buds. The tree consists of a repetitive array of its units that, like modules of other trees, arrange to a fractal-like body, with the same patterns reappearing at different scales 
(Beyhl 1995; Prusinkiewicz and Lindenmayer 2004; Ferraro et al. 2005). In terms of the tree architecture, D. draco is a Leeuwenberg's model tree (Hallé et al. 1978; Tomlinson 1983; Barthélémy et al. 1989). This model helps the tree to colonize a habitat by means of "rapidly established populations rather than individual speciation and long life span" (Hallé et al. 1978). The tree, in its natural habitat in the Cape Verde Islands, occurs as D. draco (L.) L. subspecies caboverdeana Marrero Rodr. \& R. Almeida (Marrero and Almeida 2012) and in Southwest Morocco as D. draco ssp ajgal (Benadib and Cuzin 1997). In Gran Canaria, Canary Islands, it occurs as D. tamaranae (Marrero et al. 1998)

A remarkable feature of the tree, as a modular body, is reiteration: growing dormant (axillary) buds into new modules (Hallé et al. 1978; Tomlinson 1983; Barthélémy et al. 1989). Also known as "release of suppressed/axillary buds", it comes with ageing, trauma and bending, affecting the tree growth form (e.g. Brown 1974; Shimizu-Sato and Mori 2001). It is envisaged that in a tree, active apical meristem releases auxin that inhibits the growth of lateral buds (apical dominance) so when the apex is removed (by flowering or pruning), the apical dominance stops and lateral buds awake (Brown 1974; Cline 1997). Reiteration also involves other growth hormones and genetics (Shimizu-Sato and Mori 2001).

Dracaena draco tree reiterates after flowering and trauma like other trees. This is probably associated with ceasing of apical dominance and auxin release. It also shows some other, species-specific features:

1. Rametes (new growth) appear neither on the base of the old trees (like El Drago of Icod, Fig. 7f) nor on bending trunks (e.g. Drago de Punta Gorda, Fig. 9e). We have never found them reported nor seen any, except for the "hanging basket" plant that started growing a new branch from the base of its etiolated trunk, Fig. 9j; v. We presume that even old trunk still keeps its sleeping buds there (our "Essendon" tree reiterated after its old branches removal).

2. Rametes do not grow from the roots of the tree. New growth may surround its rotted-out trunk (see Bico: Dragoeiro da Tapada, online) but it is of branches origin (Krawczyszyn and Krawczyszyn 2014). The tree grows neither root suckers nor rhizomes. We also noted lack of root suckers in Yucca elephantipes a monocot with a tree growth habit. It means that adventitious roots of these two monocots may not form the reserve buds.

3. Reiteration may also occur by means of growing massive aerial roots. They grow in response to trauma and environmental stress turning large, multi-modular units with a few sets of branches into new clones (Krawczyszyn and Krawczyszyn 2014), that is hard to explain in terms of apical dominance and auxin release, factors that play a role in reiteration of forest trees (Brown 1974; Cline 1997).

\section{Sunlight makes $D$. draco flower}

Plants flower in responses to changes in daylight length or to internal cues, autonomously. The autonomous flowerers have either long or short life cycles so they are not fussy about environment. They flower spontaneously when mature and may need only cues from environment (Kinet 1993; Davenport 2007; Wilkie et al. 2008).

Dracaena draco flowers after long period of time (at least 9 years) so it is an autonomous flowerer. It needs long time to gather resources (Lacey 1986). Significant resources must be required, considering the production of about 50,000 flowers (Symon 2004). Long delay in first flowering is associated with species longevity (Harper and White 1974). Indeed the oldest living Dragon tree, El Drago of Icod, is told to be about 400 years old (Mägdefrau 1975). Generally then, flowering of $D$. draco resembles other autonomous flowerers.

The time the plant needs to gather resources to flower depends on the quality of environment, so reduction in such a quality delays flowering (Lacey 1986). In Draco's natural habitat in the Canaries, the major factor limiting growth seems to be low annual rainfall; for half a year, the tree suffers water stress (Cabrera Pérez 1999). However, the plant seems to solve this issue by its ability to conserve water and to store it in the tissues of its massive trunk, like a botanic rainwater tank. However, as a subtropical species, it seems to be still fussy in regards to the amount of sunlight. This may explain why our plants, in Mediterranean Melbourne, mature in 9-10 years while growing in full sun, or 16-19 years in shade. Plants reported from less sunny UK flowered when about 30 years old (Smith 1851; Goodenough personal comm. 2015). Clearly then, sunlight is a key factor determining time of flowering in D. draco.

Draco's ability to delay flowering and grow remarkably tall, unbranched trunks, that Beyhl (2001) considers as "aberrant growth" is intriguing. Locals in the Canaries believe such trees may never flower and call them "Drago Macho" i.e. "male dracaena" (Carroll Humphreys personal comm. 2008). Beyhl (2001, Fig. 3) reported one that "has grown very tall in a short time in order to reach the light". We agree that such a plant will grow towards sunlight but we believe that it would grow at a constant rate so it would take a long time to grow tall. It appears from our data that our "sun" and "shade" plants grow with the same rate that is $24 \mathrm{~cm} /$ year. 
Our "Drago Macho", Fig. 7h, i about 6-7-m tall also grew in shade of the high-rise building, tilting away from it as it were seeking sunlight. This part of the city is at least 30 years old so the plant has been growing in shade for that long. Another plant, Fig. 1d about 10-12 m tall, in Jardín Botánico (La Orotava) also seems to grow shaded by the leafy trees and grew catching light from overhead. No record of its planting is available but it is reasonable to expect it was around 1788 when the "Botánico" was set up (Domínguez 2008). In 2008, we saw orange berries at its top, meaning that it must have flowered around 2007, after reaching the sunlight. Clearly then, the tree flowered for the first time after reaching the sunlight and thus ending its "Drago Macho" status. Was it after about 200 years of growth? The answer may be in the records of the Botánico. These data are consistent with our finding regarding codevelopment of trees in relation to light.

However, this is not always the case. One of such plants we saw in La Laguna (Tenerife) grew close to the house but its tip was in full sun, sticking out about $5 \mathrm{~m}$ above its roof. Also another plant in Gibraltar (Anonymous 2007) grows in full sun, next to the branching tree, and it is likely that both plants were planted at the same time. Explanation of this unusual "Drago Macho" phenomenon may come from data on Arabidopsis, a model plant in flowering research. An internal mechanism that allows it to flower is linked with the decline in concentration of a small piece of RNA called microRNA that can bind to a longer thread of messenger RNA to inhibit protein synthesis. Over time its concentration declines and when it falls below a certain level, the flowering process starts (Bergonzi et al. 2013). Mutation of microRNA in D. draco would prevent it from flowering and result in growing "Drago Macho".

\section{Genetics, environment and shaping of $D$. draco}

It is well known that a tree form develops according to its architectural model, a "genetic blueprint" and that the environment, mostly light, affects this process (Shinkle 2008). Genetics predisposes the tree to a certain form but environment decides if this form will appear or not (Hallé et al. 1978; Fisher and Hibbs 1982; Berezovskava et al. 1997; Brack 1999; Holdrege 2005; Barthélémy and Caraglio 2007; Getzin and Wiegand 2007; Hallé 2010).

The Leeuwenberg's tree model (Hallé et al. 1978) directs D. draco apical meristem in each unit to make the leaves and to elongate for a certain amount of time and then to flower. But, how long would this meristem work before it flowers depends on sunlight, Table 2. Figure 9a also shows that the length of time of vegetative growth would influence the height of the trunk. The "sun" tree $x$ flowered four times and grew a short trunk. The "shade" tree, y, missed one flowering event so it grew for longer and started to branch after reaching sunlight. It grew in concert with its neighbours by co-development. Our trees shaded by the house ("Julie", "Monsta", "Rhonda") also developed "roof high" trunks. Computer models, Fig. 9b, are also similar to our sun and shade trees. Local climate would also greatly influence the height of unbranched trunks. Our trees grew about $0.24 \mathrm{~m} /$ year and two dated trees we found in Tenerife (Casa El Drago, Icod and La Villa, La Laguna) grew $0.5 \mathrm{~m} /$ year. This explains differences in the height of the unbranching trunks in D. draco trees, Fig. 1.

Genetics also controls the location of sleeping buds via the phyllotaxis (each bud has its locus above the leaf centre), as well as a directive that flowering (trauma) is a "wake up" call to sleeping buds, to grow branches. However, all this does not predisposes the buds to grow a particular shape of the crown. In this tree model, there is no central meristem to take a role of "organizing apex" (see Hallé et al. 1978 p. 151) so all branches/units are equal and free to grow in 3D. Sachs and Novoplansky (1995) hold that a competition between growing tips of branches for light and space is a key determinant of tree form. If so, direction from which sunlight is coming from and space available would determine the shape of the crown: globular, pyramidal or irregular (Holdrege 2005; Tudge 2006).

The cycles of flowering in D. draco are innate like, for example, cyclical changes inclination (rightward or leftward) of fusiform initial cells in the vascular cambium (Krawczyszyn and Romberger 1980). Duration of flowering cycles in $D$. draco often match the 11-year cycles of increased solar activity raising a suspicion that both phenomena may be linked. The blossoming of garden plants often follows the solar cycles, and data on blossoming were used to estimate the length of the solar cycles (Allen 2002).

"Possible two forms of the species can be identified in Australia"... noted Symon (1974). Adelaide trees of Cape Verdean source (CV) have slim, short trunks and umbrellalike crowns, while of Canarian source $(\mathrm{Ci})$ have stout, tall trunks and more erect crowns, Fig. 10a. These data prompted us to explore this issue. We found that:

1. The images of the trees (on postal stamps) for these islands, Fig. 10b, c, are in concert with those in Adelaide and those of Cape Verdean origin from Portugal, due to the past ties with Cape Verde, match their lines depicted by Byström (1960), Espírito-Santo (2009) and Bico (online).

2. Both forms grow in Melbourne and also among our own plants, Fig. 10d-h. As an example, a young tree with slender trunk (Fig. 10d) branches low (Fig. 10h, i) forms wide angle between branches and the trunk as CV plants, while plant Essendon fits descriptions of $\mathrm{Ci}$ form (Beyhl 1995). 

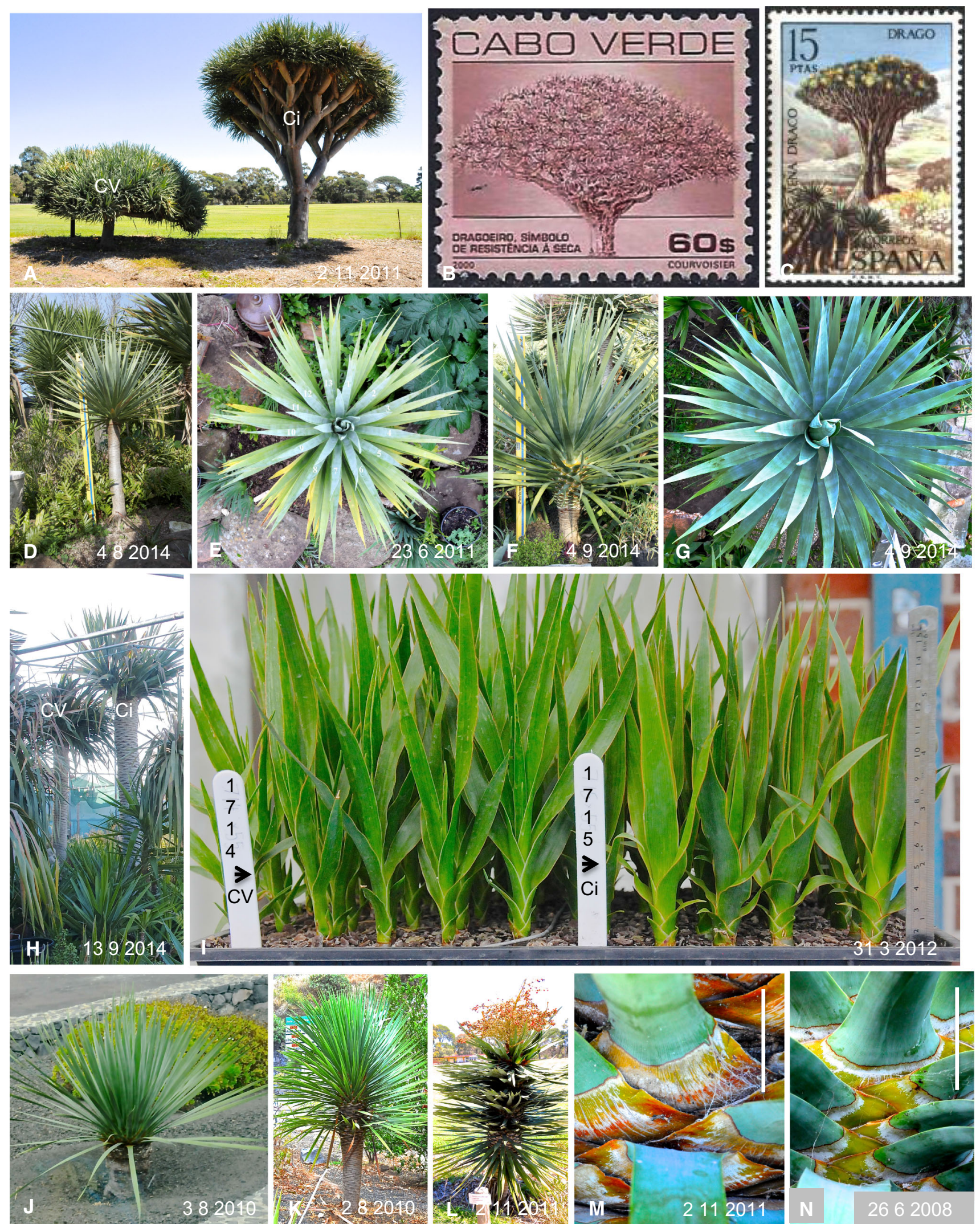
4Fig. 10 Genetic control of growth form in D. draco. a Advanced trees (no. 1714 and 1715, left and right, respectively), representing the Cape Verdean (CV) and Canarian (Ci) growth forms in Waite Arboretum Adelaide Univ., Australia. Tree no. 1714 originated from the seed of the CV tree presented in Fig. 7k and 1715-from the seed collected in La Palma, the Canary Islands. Both seeds were planted in 1957, see Symon (1974). b, c Images of two growth forms of D. draco on the postal stamps of Cape Verde Islands and the Canary Islands. d, e 8-year-old tree with the features of Cape Verdean (CV) growth form. $\mathbf{f}, \mathbf{g}$ 4-year-old trees with features of Canarian (Ci) growth form. Plant in $\mathbf{f}$ is from the seed brought from Tenerife, Canary Islands. h 2 adolescent trees with features of $\mathrm{CV}$ and $\mathrm{Ci}$ growth forms. i 6-monthold seedlings originated from the seeds of plants in Fig. 10a. (Seeds courtesy of Dr. Gardner and Dr. Symon). j, k Two young, human planted plants with very narrow, stift and prickly leaf blades in La Palma. 1 D. draco ssp ajgal in Waite Arboretum Univ. of Adelaide, Australia. It originated from the seed collected in Nth Africa by Dr. F Beyhl, soon after its discovery by Benadib and Cuzin in 1997. m, $\mathbf{n}$ Bases of the leaves of ssp ajgal (from $\mathbf{l}$ ) and, $\mathbf{n}$, one of our plants in Melbourne with some morphological features of $D$. draco ssp ajgal. Scale in $\mathbf{d}, \mathbf{f}, \mathbf{h}$ is $1.2 \mathrm{~m}$, in $\mathbf{i} 30 \mathrm{~cm}$. Scale bars in $\mathbf{m}$ and $\mathbf{n}$ are $4 \mathrm{~cm}$

3. Seedlings from the exemplary trees no 1714 and 1715 in Adelaide, we grew (seeds courtesy of Dr. Gardner and Dr. Symon) differ in the size of the stems and the leaves, Fig. 10i.

4. Both, Canarian and Cape Verdean archipelagos share the same geological history (Patriat and Labails 2006) but are about $1400 \mathrm{~km}$ apart from each other. Parting of two populations with no interbreeding speaks for the species disjunction and evolving into different forms. Similar disjunction of Nth African and Canarian trees led to rise of its African subspecies D. draco ssp. ajgal already (Benadib and Cuzin 1997).

These data further support the view that the $\mathrm{CV}$ and $\mathrm{Ci}$ forms are related to geography. This also means that the size of the trunk and the shape of the crown are controlled genetically. Final evidence would require the seedlings from plants 1714 and 1715 years to grow their crowns or, perhaps, DNA analysis (Petroncini et al. 2003; HellerUszyńska et al. 2011).

Apparently, this issue was studied from the plant taxonomy perspective by Marrero and Almeida (2012). They found that canarian and capeverdean plants differ also in many other features (e.g. the shape of the pedicels and the size of fruits and seeds) so that they classify capeverdean plants as a new taxon: Dracaena draco (L.) L. subspecies caboverdeana Marrero Rodr. \& R. Almeida. This distinction means that not only the shape the bole and the crown but also other features are controlled genetically in this tree.

Latitude and air humidity also affect growth form of $D$. draco (Byström 1960) as well as strong, unidirectional wind, Drago de Punta Gorda, Fig. 9e. Vandelli tree (see: Biko online) shows deformity from their own weight. Trauma (sunburns, herbivory) would cause juvenile plants to branch and older ones to grow large, aerial roots that would further distort the growth form (Krawczyszyn and Krawczyszyn 2014). Overnutrition causes excessive growth (Beyhl 2001) while scarce space- nutritional dwarfism, Fig. 9h, i. The trees in La Palma (Garafia), Fig. 9f, are of the anthropic origin (Pérez online).

The variations in the population of $D$. draco in the Canary Islands are little known. In La Palma, we saw young, park trees with distinctly narrow, sturdy blades and prickly tips, Fig. 10j, k, resembling D. draco ssp ajgal tree in Adelaide, Fig. 101. One of our plants in Melbourne (Fig. 10n), we bought in a local nursery is also like that. It had leaves similar to ajgal in Adelaide, Fig. 10m, n. Also its berries and seeds, from flowering in 2014, were smaller than in our other dracos and little different from those of subspecies ajgal in Adelaide. This suggests that the population of $D$. draco is more varied than may appear from up to date research.

\section{Growth imbalances and tilting}

Vertical stem is vital for a tree's mechanical stability. Any Dicot or Conifer tree forced off vertical returns in time to its original position by making reaction wood, RW. The branches also form RW to resist the force of gravity and keep horizontal. RW is the tree's mechanical stability device (Sinnott 1952; Brown 1974; Timell 1986; Schweingruber 2007; Ruelle 2014). In this respect, leaning massive trunks of $D$. draco, Fig. 7d, e, seem extraordinary and resemble "drunken trees" in tundra: when melting permafrost causes them to lose ground and tilt indiscriminately (Rozell 1995). The Draco tilts on solid ground and always towards the sun. The two trees (Fig. 7d, e) tilt like that shaded by tall buildings. They tilt from the bases as if they grew like that right from their planting. Similar, though less dramatic leaning, we also noted in our 5-m tall Yucca elephantipes trees that grew on the edge of the group, exposed to full sun (while those in the middle of the group had vertical trunks). Clearly they do not balance their trunks as Conifers and Dicots trees do.

Adolescent Dragon tree, 2-3-m tall with club-like stem widening towards the top (Figs. 5a-d, 7a) with a heavy head of leaves followed by a 6-7 kg load of berries (Symon 2004) can easily be knocked off the vertical. Later, as re-branching goes on, mechanically speaking, the centre of gravity shifts even more to the outside of the tree base. Momentum builds and this, combined with softened by rain soil (Lyons 1974), may lead to its up rooting, Fig. 7k. In botanic terms, this comes from both strong, positive phototropism of its growing tips and inadequate gravitational response of its secondary body. 
Conifer and Dicot trees grow reaction wood (RW) as an inborn, gravitropic response to reinforce their structure and to redirect growth. This involves:

1. Eccentric, secondary xylem deposits ("adaptive growth", see Del Tredici 2013) due to increase in local activity of the vascular cambium, VC. This reinforces the stem on the compression side (Conifers) and tension side (Dicots) of the trunk and the branches.

2. Special, structural features. As an example, Conifers have tracheids with thick walls and large intracellular spaces between their radial rows. Hydrated, they elongate bringing the stem to the vertical and the branch to the horizontal positions.

3. Hormones, especially auxin, rather than physical force (compression and tension), play a role in RW appearance (Brown 1974; Timell 1986; Jaffe et al. 2002; Nishikubo et al. 2007; Brereton et al. 2012).

Wheat farmers know that heavy rain late in the plant cycle can flatten the crop and destroy it, but if it falls earlier, younger plants can straighten up and resume upward growth (Blancaflor and Masson 2003). Similar responses noted Fisher (1975) in horizontally placed seedlings of Dracaenas, Cordylines and Yuccas: only parts with primary tissues would straighten. Among details of this inertia of secondary body, Fisher noted eccentric growth (i.e. thicker tissues deposits of the on the lower side), some changes in the size of the vascular bundles and in degree of lignification (some of them being species specific). In all cases, there was no reaction wood, RW (Fisher 1975; Fisher and Marler 2006).

These data have also implications for D. draco.

1. Presence of symmetric deposits of secondary tissue on a cross section of the unit (i.e. the scar of stem/branch) would mean vertical growth of the unit, while eccentric - growth off the vertical. The photos in Fig. 8a-d show irregular scars, and each has its own story. As an example, units in a and b grew vertically, before growing off the vertical, while two units in d used to grow horizontally. Growth off the vertical is indicated by eccentric growth i.e. increased deposits of the secondary tissues on the lower side of the unit. We can also expect that in lower sides of the branches a-d, the vascular bundles were larger than on upper and they are indeed (Table 4) like in D. fragrans (Fisher 1975).

2. The eccentric radial growth must have reinforced the branches yet this was inadequate to overcome the force of gravity as the branches in Fig. 8a-d kept on leaning until they were removed. Horizontally arranged branches in the historical Vandelli tree in Lisbon also were removed after crushing under their own weight, Fig. 9d (Espírito-Santo 2009; Bico online).
3. The enhanced growth of the lower side in the leaning unit and tracheids (Rauwenhoff 1863; Wossidlo 1868) D. draco shares with Conifers, and nothing else. Monocots grow by means of secondary thickening meristem, STM, (or monocot cambium) that is not homologous to the vascular cambium (VC) of Conifers (Cheadle 1937; Carlquist 2012). Also their derivative tissues differ mechanically from one another: the first ones are quite flexible, easy to bend, while the second ones are rigid, with high bending-resistance. We noted that the mature branch of the dragon tree is not flexible; it does not bend like a branch of a typical Dicot or Conifer tree. When pressured, it rather moves together with the rest of the tree as if the whole tree were a monolith. Such a branch (with vascular bundles spread out along the perimeter, among small, parenchyma cells and with hollowed area of primary vascular bundles (usually rotted out) is structured like a reinforced, concrete pipe and it works as one. Similarly, the aerial roots that grow from the bases of the branches aligning with the trunk cannot be separated from the trunk even if a strong force is applied (Krawczyszyn and Krawczyszyn 2014). Clearly, the monocot tissues give the $D$. draco body enormous strength but this comes together with stiffness.

Mechanical forces affect plant functioning but to detect and to respond to such forces, plant needs to be structured mechanically (Kasprowicz et al. 2011). Stem of D. draco, like the mature wheat's straw, is not structured to restore its verticality after strong, phototropic response of its growing tips.

Author contribution statement JK-study concept and design. Writing the article. TK-planting, plants care and technical assistance. Both authors travelled to botanical gardens in Melbourne area, Australia, and to Canary Islands, Spain.

Acknowledgments We thank Dr. FE Beyhl and Dr. F Armitage for reviewing the manuscript, Dr. J Gardner and Dr. DE Symon for the seeds of 1714, 1715 trees, Dr. MD Espírito-Santo and Dr. E Ślesak for some important references, M. Bico and Ediciones of Tenerife for permission to use photographs and Dr. MT Krawczyszyn for support during this project. We are grateful to A Alvares, R Baldwin, JL Diaz, $\mathrm{S}$ Goodenough, P Carroll-Humphreys for data on the dragon trees in Tenerife, UK and USA, and F Javier, pension Mova St. Cruz de Tenerife, for hospitality.

\section{Compliance with ethical standards}

Conflict of interest The authors declare that they have no conflict of interest.

Open Access This article is distributed under the terms of the Creative Commons Attribution 4.0 International License (http://crea tivecommons.org/licenses/by/4.0/), which permits unrestricted use, distribution, and reproduction in any medium, provided you give appropriate credit to the original author(s) and the source, provide a 
link to the Creative Commons license, and indicate if changes were made.

\section{References}

Allen H (2002) Historical and Recent Solar Activity and Geomagnetic Storms Affecting Spacecraft Operations, SCOSTEP, GOMAC 2002 Session 14: Modern Space Systems Issues 11-14 March in lower-middle Yangtse River Valley and its relation with solar-cycle length. Geophys Res Lett 21(24):2693. doi:10.1029/94GL0266

Anonymous (2007) Dragon tree Dracaena Draco. The Gibraltar Ornithological and Natural History Society, Gibraltar 2007 week 52 online. Accessed 9 Nov 2014

Barthélémy D, Caraglio Y (2007) Plant architecture: a dynamic, multilevel and comprehensive approach to plant form, structure and ontogeny, Ann Bot 99:375-407. doi:10.1093/aob/mcl260. http://aob.oxfordjournals.org/content/99/3/375.

Baldwin R (2014) Dragon Tree Quest. http://www.smgrowers.com/ info/Dracaena_dracoSantaBarbara.asp. Accessed 20 June 2015

Barthélémy D, Edelin C, Hallé F (1989) Architectural concepts for tropical trees. In: Holm-Nelsen LB, Balslev H (eds) Tropical forests: botanical dynamics, speciation and diversity. Academic Press, London, pp 89-100

Benadib A, Cuzin F (1997) Populations de dragonnier (Dracaena draco L. subsp. ajgal Benadib et Cuzin) au Morocco: valeurs taxonomique, Biogeographique et phytosociologique. Competes Rendus de l'Academie des Sciences-Series III-Sciences de la Vie 320:267-277

Berezovskava FS, Karev GP, Kisliuk OS, Khlebopros RG, Tsel'niker YL (1997) A fractal approach to computer-analytical modelling of tree crowns. Trees 11:323-327

Bergonzi S, Albani MC, Loren van Themaat EV, Nordstrom KJV, Wang R, Schneeberger K, Moerland PD, Coupland G (2013) Mechanisms of age-dependent response to winter temperature in perennial flowering of arabis alpina. Sci 340(6136):1094. doi:10. 1126/science. 1234116

Beyhl FE (1995) [PDF] Two different growth forms of dracaena draco 1. publications.cm-funchal.pt/bitstream/100/1023/1/ Bolmmf_s04A_1995_pp091-093.pdf

Beyhl FE (1996) The emta tree (Euphorbia arbuscula Balf. Fil.), a succulent tree of Dracoid habitus from the island of Soqotra (Dicotyledones: Tricoccae: Euphorbiaceae). In: Proceedings of the first international symposium on Soqotra Island: present and future. UN Public, pp. 115-122

Beyhl FE (2001) Dragon trees (Dracaena draco L.) with aberrant growth forms (Monocotyledones: Lilliflorae: Agavaceae) Fauna and Flora of the Atlantic Islands. http://www.horta.uac.pt/ intradop/images/stories/arquipelago/sup2b/supl2b.pdf. Accessed 7 May 2014

Bico M Dragoeiros de Vandelli, Jardim Botânico d'Ajuda, Lisboa. http://www.panoramio.com/user/5707675/tags/Dragoeiros\%20de \%20Lisboa) Accessed 1 May 2014

Bico M (Palácio Pancas, em Lisboa http://www.panoramio.com/ photo/64643207). Accessed 5 July 2014

Blancaflor EB, Masson PH (2003) Plant Gravitropism. Unravelling the ups and downs of a complex process. http://www. plantphysiol.org/cgi/doi/10.1104/pp.103.032169

Brack C (1999) Tree shape. http://fennerschool-associated.anu.edu. au/mensuration/shape.htm. Accessed 15 Jan 2012

Brereton NJB, Ray MJ, Shield I, Martin P, Karp A, Murphy RJ (2012) Reaction wood-a key cause of variation in cell wall recalcitrance in willow. Biotechnol Biofuels 5:83. doi:10.1186/ 1754-6834-5-83

Brown CL (1974) Growth and Form. In: Zimmermann MH, Brown CL (eds) Trees structure and function, 2nd edn. Springer-Verlag, New York, pp 125-167

Byström K (1960) Dracaena draco L. in the Cape Verde Islands. Acta Hortic Götobg 23:179-214

Cabrera Pérez MA (1999) Visit native flora of the Canary Islands. Editorial Everest SA, Spain

Carlquist S (2012) Monocot xylem revisited: new information, new paradigms. Bot Rev 78:87-153. doi:10.1007/s12229-012-9096-1

Casper SJ (2000) Die Geschichte des Kanarischen Drachenbaumes in Wissenschaft und Kunst. Haussknechtia Beiheft 10. Jena

Chase MW, Reveal JL, Fay MF (2009) A subfamilial classification for the expanded asparagalean families Amaryllidaceae, Asparagaceae and Xanthorrhoeaceae. Bot J Linn Soc 161:132-136. doi:10.1111/j.1095-8339.00999.x

Cheadle VI (1937) Secondary growth by means of a thickening ring in certain monocotyledons. Bot Gaz 98:535-555

Cline M (1997) Concepts and terminology of apical dominance. Am J Bot 84:1064-1069

Davenport LT (2007) Reproductive physiology of mango. Rev Braz J Plant Physiol 19:4. http://dx.doi.org/10.1590/S1677-0420200 7000400007

Del Tredici P (2002) Gestalt dendrology: Looking at the whole tree. Arnoldia 61:3-8

Del Tredici P (2013) Tree architecture definitions. http://www. arboretum.harvard.edu/wp-content/uploads/Tree-Architecture. pdf

Domínguez B (2008) Tenerife, Tourist guidebook. Ediciones AM, Tenerife. ISBN 978-84-95822-38-3

Dyrynda P (1986) Defensive strategies of modular organisms. Phil Trans R Soc Lond B 313:227-243

Espírito-Santo MD (2009) O dragoeiro e Vandelli. O Botânico. 3: 6-7. Revista da Associação Ibero-Macaronésica de Jardins Botânicos. Alcalá de Henares. http://www.elbotanico.org/ revista3_articulos/dragoeiro_vandelli_dalila_espirito_santo.pdf

Ferraro P, Godin C, Prusinkiewicz P (2005) Toward a quantification of self-similarity in plants. Fractals 13:91-109. doi:10.1142/ S0218348x05002805. http://hal.inria.fr/docs/00/30/74/02/PDF/ view.pdf

Fisher JB (1975) Eccentric secondary growth in Cordyline and other agavaceae (Monocotyledonae) and its correlation with auxin distribution. Am J Bot 62:292-302

Fisher JB, Hibbs D (1982) Plasticity of tree architecture: specific and ecological variations found in Aubreville's model. Am J Bot 69:690-702

Fisher JB, Marler TE (2006) Eccentric growth but no compression wood in a horizontal stem of Cycas micronesica (Cycadales). IAWA J 27:377-382

Gebauer A (2009) Alexander von Humboldt. Seine Woche auf Teneriffa 1799. Santa Ursula (Teneriffa) Spain, Zech Verlag

Getzin S, K Wiegand (2007) Asymmetric tree growth at the stand level: Random crown patterns and the response to slope. For Ecol Manag 242:165-174, Elsevier. http://www.sciencedirect. com

Guerra AS (2010) Iconografías draconianas: paseos por el arte y la ciencia. http://www.rinconesdelatlantico.es/num6/lector.php?id= 166. Accessed 5 Mar 2015

Hallé F (2010) Architectural variation at the specific level in tropical trees. In: Zimmermann MH, Tomlinson PB (eds) Tropical trees as living systems. Cambridge University Press, Cambridge, pp 209-221

Hallé F, Oldeman AA, Tomlinson PB (1978) Tropical trees and forests, an architectural analysis. Springer-Verlag, Berlin 
Harper JL, White J (1974) The demography of plants. Ann Rev Ecol Syst 5:419-463. http://links.jstor.org/sici?sici=0066-4162\% $281974 \% 295 \% 3 \mathrm{C} 419 \% 3 \mathrm{ATDOP} \% 3 \mathrm{E} 2.0 . \mathrm{CO} \% 3 \mathrm{~B} 2-\mathrm{J}$

Heller-Uszyńska K, Uszyński G, Huttner E, Evers M et al (2011) Diversity Arrays Technology effectively reveals DNA polymorphism in a large and complex genome of sugarcane. Mol Breed 28:37-55

Holdrege C (2005) The forming tree, In Context No 14. A Publication of The Nature Institute, pp 3-6. http://natureinstitute.org/pub/ic/ ic $14 /$ trees.htm

Jaffe MJ, Leopold AC, Staples RC (2002) Thigmo responses in plants and fungi. Am J Bot 89:375-382

Jorgensen TH, Olesen JM (2000) Growth rules based on the modularity of the Canarian Aeonium (Crassulaceae) and their phylogenetic value. Bot J Linn Soc 132:223-240. doi:10.1006/ boj1.1999.0294

Kasprowicz A, Smolarkiewicz M, Wierzchowiecka M et al (2011) Introduction Tensegral world of plants. In: Wojtaszek P (ed) Mechanical integration of plant cells and plants. SpringerVerlag, New York. doi:10.1007/978-3-642-19091-9

Kinet JM (1993) Environmental, chemical, and genetic control of flowering. Hortic Rev 15:279-334

Krawczyszyn J, Krawczyszyn T (2014) Massive aerial roots affect growth and form of Dracaena draco. Trees. doi:10.1007/s00468014-0987-0. http://link.springer.com/article/10.1007\%2Fs00468014-0987-0

Krawczyszyn J, Romberger JA (1980) Interlocked grain, cambial domains, endogenous rhythms, and time relations, with emphasis on Nyssa sylvatica. Am J Bot 67(2):228-236

Krawczyszyn J [PDF] THE DRAGON TREE - Dracaena Draco Farm http://www.dracaenadraco.com/index_files/dracaenadraco farm.pdf. Accessed 2 Feb 2015

Lacey EP (1986) Onset of reproduction in plants: size versus age dependency Trends Ecol Evol 1:72-75. http://www.elsevier.com

Lyons G (1974) In search of Dragons. Cactus Succul J (US) 46:267-282

Mandelbrot B (1982) The fractal geometry of nature. Freeman WH \& Co, USA

Marrero A, Almeida RAS (2012) A new subspecies, Dracaena draco (L.) subsp. caboverdeana Marrero Rodr. \& R. Almeida (Dracaenaceae) from Capo Verde Islands. Int $\mathrm{J}$ of Geobot Res 2(2):35-40. http://www.editaefa.com/uploads/Ref.Dracaena draco-refs-2012-11-5.pdf

Marrero A, Almeida RS, Gonzales-Martin M (1998) A new species of the wild dragon tree, Dracaena (Dracaenaceae) from Gran Canaria and its taxonomic and biogeographic implications. Bot $\mathrm{J}$ Linn Soc 128:291-314

Mägdefrau K (1975) Das Alter der Drachenbäume auf Tenerife. Flora $164: 347-357$

Mori A, Niimets U (2010) Plant responses to heterogeneous environments. Ecol Res 25:691-692. doi:10.1007/s11284-0100696-0

Nishikubo N, Awano T, Banasiak A, Bourquin V, Ibatullin F, Funada R, Brumer H, Teeri TT, Hayashi T, Sundberg B, Mellerowicz EJ (2007) Xyloglucan endo-transglycosylase (XET) functions in gelatinous layers of tension wood fibers in poplar-a glimpse into the mechanism of the balancing act of trees. Plant Cell Physiol 48:843-855

Ommen K (2009) [PDF] Carolus: the exotic world of Carolus Clusius (1526-1609). Kleine publicaties van de Leidse Universiteitsbibliotheek Nr.80. https://openaccess.leidenuniv.nl/bitstream/KP\% 2080\%20scherm.pdf

Patriat M, Labails C (2006) Linking the Canary and Cape-Verde hotspots Northwest, Africa. Mar Geophys Res 27:201-215. doi:10. 1007/s11001-006-9000-7
Pérez RAS. Los dragos del archipiélago canario http://www. rinconesdelatlantico.es/num6/142.html

Petroncini S, Marcheselli MP, Bruschi P (2003) Preliminary aspects of the anatomy and genetic variability of Dracaena cinnabari Balf. fil: a threatened endemic species of Socotra Island, South Yemen. J Agric Environ Int Dev 97(3/4):185-195

Prusinkiewicz P, Lindenmayer A (2004) The algorithmic beauty of plants. Springer-Verlag, New York. http://algorithmicbotany. org/papers/abop/abop.pdf

Rauwenhoff NWP (1863) Bijdraage Tot De Kennis Van Dracaena Draco L. CG Van Der Post Amsterdam. Kessinger Legacy Reprints USA

Rozell N (1995) Formerly Frosty Footing Causes Drunken Forests. Artic Alaska Science Forum. Geophysical Institute, University of Alaska Fairbanks. Accessed 15 Aug 2014

Ruelle J (2014) Morphology, anatomy and ultrastructure of reaction wood. In: Gardiner B et al (eds) The biology of reaction wood, Springer series in wood science. Springer-Verlag, Berlin, pp 13-35

Sachs T, Novoplansky A (1995) Tree form: architectural models do not suffice. Isr J Plant Sci 43:203-212

Schweingruber FH (2007) Wood structure and environment, Springer series in wood science, p 127-137. ISBN: 978-3-540-48548-3 (Online)

Shimizu-Sato S, Mori H (2001) Control of outgrowth and dormancy in axillary buds. Plant Physiol 127:1405-1413. doi:10.1104/pp. 010841

Shinkle J (2008) Basic photomorphogenesis. http://www.photobiol ogy.info/Shinkle.html. Accessed 15 Nov 2014

Sinnott EW (1952) Reaction wood and the regulation of tree form. Am J Bot 30:69-78

Smith, J (1851) Dracæna Draco. Dragon's-blood Tree. In: Hooker WJ, Smith J (eds) Curtis's Bot Magaz, vol 77, Nr. 4571 (6 pages +1 plate). London (UK). http://www.biodiversitylibrary. org/item/14355-page/61/mode/1up

Symon DE (1974) The growth of Dracaena Draco-Dragon's blood tree. J Arnold Arbor 55:51-58

Symon DE (2000) Dragon's blood tree. Mediterr Gard Soc 21:30-32

Symon DE (2004) Fifty thousand flowers. Cactus and Succul J $76: 132-133$

Timell TE (1986) Compression wood in gymnosperms, vol 1-3. Springer-Verlag, New York

Tomlinson PB (1983) Tree architecture. Am Sci 71:141-149

Tudge C (2006) The secret life of trees. How they live and why they matter

von Humboldt FHA (1850) Views of nature, or contemplation on the sublime phenomenon of creation, English edn. HG Bohn, London

Wilkie JD, Sedgley M, Olesen T (2008) Regulation of floral initiation in horticultural trees. J Exp Bot 59(12):3215-3228. doi:10.1093/ jxb/ern 188

Wossidlo P (1868) Ueber Wachstum und Structur der Drachenbäume. Jahresbericht. d. Realschule am Zwinger in Breslau für:1-32

http://www.veac.vic.gov.au. Accessed 10 Feb 2015

http://www.Youtube:Fractaltrees. Accessed 15 Feb 2014

http://www.dracaenadraco.com. Accessed 20 June 2015

Wyk B, Wyk P (2007) How to indentify trees in Southern Africa, Struik Publ Cape Town. https://books.google.com/books?id= 9HOmOEIZL6IC. Accessed 10 Feb 2015

Zimmermann MH (1969) Vascular anatomy of monocotyledons with secondary growth-an introduction. J Arnold Arbor 50:159-179. http://www.encyclopedia.com/doc/1O14-modularorganism.html. Accessed 2 June 2013 